UDC: $504.064(262.5)(477.74)$

Yevhen Volodymyrovych Sokolov,

$\mathrm{PhD}$ (Biology), Senior Researcher,

State Institution «Institute of Marine Biology of the NAS of Ukraine»,

37 Pushkinska St., Odessa, 65011, Ukraine,

e-mail: sokolovev87@gmail.com, https://orcid.org/0000-0002-0587-2719;

Roman Ivanovych Shevchenko,

$\mathrm{PhD}$ (Engineering Sciences), Associate Professor of the Department of Ecology and

Environmental Technologies, «Odesa National Academy of Food Technologies»,

112 Kanatna St., Odessa, Ukraine, 65039,

e-mail: onaft.eko@gmail.com, https://orcid.org/0000-0002-7924-1987;

Mariia Mykhailivna Madani,

$\mathrm{PhD}$ (Engineering Sciences), Associate Professor of the Department of Ecology and

Environmental Technologies, «Odesa National Academy of Food Technologies», e-mail: madanikader50@ gmail.com, http://orcid.org/0000-0001-9386-7364

\title{
ECOLOGICAL ASSESSMENT OF THE TERRITORIAL COMPLEXES OF TATARBUNARS'KYI DISTRICT OF ODESSA REGION
}

\begin{abstract}
Є. В. Соколов, Р. І. Шевченко, М. М. Мадані. ЕКОЛОГІЧНА ОЦННА ТЕРИТОРІАЛЬНИХ КОМПЛЕКСІВ ТАТАРБУНАРСЬККОГО РАЙОНУ ОДЕССЬКОЇ ОБЛАСТІ. Проведена геоекологічна оиінка ландшафтно-господарської структури Татарбунарського району на основі просторового геоінформаційного аналізу даних дистанційного зондування Землі. Проаналізований розподіл прогріву різних типів угідь району та амплітуду їх коливань на основі термальних сканерів - TIRS (Thermal InfraRed Sensor) супутника Landsat8. Проведений сезонний аналіз динаміки рослинного покриву за значеннями вегетаиійного індексу NDVI. Дана просторова характеристика зволоженості різних типів угідь території району на основі індексу NDMI. За иими показниками продемонстровано, шео сільськогосподарські орні землі мають значно більшу гетерогенність та сезонну динаміку, ніж інші типи наземних угідь. На ділянці ріллі району з засіяними та розораними землями був проведений порівняльний регресійно-кореляиійний аналіз функціональних показників: прогріву, розвитку рослинності та зволоженості, встановлений статистично-значущий зв'язок між ними. Проведена інвентаризація ландшафтногосподарської структури району за типом угідь, проаналізована екологічна збалансованість та рівень антропогенної трансформації природно-територіальних комплексів. Запропонована екологічно-збалансована територіальна структура організачії угідь та заходи з підвищення екологічної стабільності агроландиафтів району. На основі аналізу геоморфологічних особливостей району з використанням иифрових моделей рельєфу SRTM виділені ділянки, які в першу чергу мають найбільший екологічний ризик екзогенних процесів та впливу антропогенних чинників. Був побудований розподіл населених пунктів та шільності населення на території Татарбунарського району, який продемонстрував, що більшість з них розміщена саме на цих ділянках. Проведене гідрографічне районування з виділенням водозбірних басейнів та суббасейнів району. Проведений детальний гідрологоморфологічний аналіз водозбірного басейну л. Карачаус який належить до Тузловського комплексу, на підставі якого були запропоновані рекультивачійні та природоохоронні заходи.
\end{abstract}

Ключові слова: Татарбунарський район, північно-західне Причорномор'я, ГІС аналіз, дистанційне зондування, антропогенне навантаження, природно-територіальні комплекси, еколого-господарський баланс, екологічний менеджмент.

Е. В. Соколов, Р. И. ШевченКо, М. М. МаданИ. ЭКОЛОГИЧЕСКАЯ ОЦЕНКА ТЕРРИТОРИАЛЬНЫХ КОМПЛЕКСОВ С ИСПОЛЬЗОВАНИЕМ ГИС НА ПРИМЕРЕ ТАТАРБУНАРСКОГО РАЙОНА. Проведена геоэкологическая оценка ландшафтно-хозяйственной структуры Татарбунарского района на основе пространственного геоинформационного анализа и данных дистанциионного зондирования Земли. Проанализировано распределение прогрева различных типов угодий района и амплитуда их колебаний на основе термальных сканеров - TIRS (Thermal InfraRed Sensor) cnymника Landsat8. Проведен сезонный анализ динамики растительного покрова по значениям вегетационного индекса NDVI. Дана пространственная характеристика увлажненности различных типов угодий территории района на основе индекса NDMI. По этим показателям продемонстрировано, что сельскохозяйственные пахотные земли имеют значительно большую гетерогенность и сезонную динамику чем другие типы наземных угодий. На участке пахотного поля с засеянными и распаханными землями был проведен сравнительный регрессионно-коррелячионный анализ функииональных показателей: прогрева, развития растительности и увлажненности, установлена статистически значимая связь между ними. Проведена инвентаризачия ландшафтно-хозяйственной структуры района по типу угодий, проанализирована экологическая сбалансированность и уровень антропогенной трансформации природно-территориальных комплексов. Предложена экологически сбалансированная территориальная структура организации угодий и мероприятия по повышению экологической стабильности агроландшафтов района. На основе анализа геоморфологических особенностей района с использованием ичировых моделей рельефа SRTM выделены участки, которые в первую очередь имеют наибольший экологический риск экзогенных процессов и влияния антропогенных факторов. Было построено распределение населенных пунктов и плотности населения на территории Татарбунарского района, которое показало, что большинство из них размещено именно на этих участках. Проведено гидрографическое районирования с выделением водосборных бассейнов и суббассейнов района. Проведен детальный гидрологоморфологический анализ водосборного бассейна л. Карачаус который относится к Тузловскому комплексу, на основании которого были предложены рекультивачионные и природоохранные мероприятия.

Ключевые слова: Татарбунарский район, северо-западное Причерноморье, ГИС анализ, дистанционное зондирование, антропогенная нагрузка, природно-территориальные комплексы, эколого-хозяйственный баланс, экологический менеджмент.

(C) Sokolov Ye.V., Shevchenko R.I., Madani M.M.

https://doi.org/10.26565/2410-7360-2020-52-16 
Formulation of the problem. Tatarbunars'kyi District is located in the southwestern part of Odessa region and reflects the main landscape and economic features of the region: aquatic, agricultural, resort resources, and nature conservation areas. On the other hand, it is a typical District with extensive land plowing, with a dominant anthropogenic influence in the form of agricultural activities which consist of $91 \%$ of the total area of agricultural territories that are presented by arable land, while $4.16 \%$ of the arable land is degraded [8]. That information alone is enough to come to a conclusion that such land structure and resource management has a complex negative impact on ecological and economic processes, and cannot ensure sustainable development of the region, it is particularly antagonistic to the unique transitional wetland ecosystems of international importance [20], located within the area (degradation of watercourses, siltation, xenobiotic contamination, eutrophication, reduction of biological diversity, etc.)

Earth remote sensing (ERS) data - spectrozonal satellite images, digital terrain models, and geoinformation systems (GIS) - can be involved in addressing the region's balanced environmental management problems, as it provides simultaneous coverage of the whole region under study, regular monitoring and significant reduction of the cost of expensive expedition work, allowing to obtain a large array of characteristics of the status of territorial complexes of the area. Remote methods are based on the ability of spatial objects to emit, scatter, and absorb electromagnetic waves of varying intensity. The value of environmental indicators based on ERS is found like a function of the amount of reflected or absorbed radiation, which contributes to its remote identification [29].

Analysis of recent research and publications. Quantitative methods, based on the ratio of natural and anthropogenic elements [27], for estimating anthropogenic changes of landscapes have become the most prevalent for assessing the level of transformability of natural-territorial complexes. Methods of landscape and ecological optimization, as well as estimation of economic and ecological balance of the region based on the inventory of the areas with their ranking according to the degree of anthropogenic changes are presented in the works of B.I. Kochurov (1999) [11] and L.P. Tsaryk (2009) [33]. An integrated approach to the sustainable management of the usage of administrative territorial units is discussed in the following works [39, 40, 41, 42, 45, $51,55]$.

Several issues regarding Ukraine's planning of the land-usage structure were addressed with the consideration of international experience, natural and economic features $[17,47,48,50]$.
In the works of the Institute of Plant Physiology and Genetics of the NAS of Ukraine and the Space Research Institute of the NASU-SSAU (including joint ones) methods for assessing the characteristics of terrestrial plant biomass from spectra reflection (spectral signatures) were developed and proposed, issues of satellite data validation using spectrometric field measurements were considered $[10,7,18,35]$.

In the monograph of V.I. Lyalko and M.O. Popov the following issues of multispectral space information application for solving nature management problems were considered: establishment of forests' species composition; forecasting of grain yields; determination of the geo-ecological status of natural technogenic systems, etc.; materials, methods, and models of interpretation of Earth remote sensing data for environmental monitoring were outlined [12].

The use of spectroradiometer data, the Landsat and MODIS series of satellites in particular, in the assessment of thermal fields and the moisture content of artificial and natural terrestrial surfaces (territorial complexes) is reviewed in the works [9, 26, 32].

Adaptive-landscape principles of applying field-protecting forest cultivation, including the area of required field-protecting forest areas [5], were reviewed in Odesa region, including Tatarbunars'kyi District.

The environmental status of land resources of the mentioned District has been estimated based on plowing indicators, humic matter content, environmental sustainability, erosion, and others, including integral indices [28]. It is clearly demonstrated that the land resources of the area do not meet the requirements of rational natural use due to, first of all, the violation of the ratio of arable land.

Recommendations for the location of agricultural crops are proposed, and so is the use of ERS data for the quantitative assessment of vegetation of Tatarbunars'kyi District [2]. An assessment of the recreational potential of the administrative regions of Odesa region by the integral characteristics of the resource, ecological, infrastructural, and consumer factors is carried out in [6], where it is shown that Tatarbunars'kyi District is very promising for studies of ecological tourism, balneology, and recreation at the expense of a large number of objects of nature conservation fund, firth and estuary natural complexes. Structural features of the eco-network, including the objects of the nature conservation fund, their territories and prospects for expansion [20], are also taken into consideration. An analysis of natureprotecting regime of coastal protection lanes (CPL) of Tatarbunars'kyi District's hydro-ecosystems and their structures has been reviewed in [25] and it is 
noted that the District is characterized by a very little amount of CPLs with corresponding project documentation. In the very same work, there is an analysis of the problems of efficient and integrated use of the Sasyk estuary that was desalinated as a result of river water transmission from the Danube-Sasyk channel. Collective works $[1,27]$, with a consideration of anthropogenic influence, have analyzed the peculiarities of hydrological, hydro-chemical and hydro-biological regimes of the ecosystems of estuary complexes located within the area, estuaries of the «Tuzlov group» (Shagany, Alibey, Burnas) in particular. The morphometry and toponymy of the water bodies of the «Tuzlovs'kyi estuaries» national park were also discussed in [19]. For these objects, a comparative classification according to morphometric and hydrological characteristics, as well as their natural resistance, has been conducted [14, 31].

Highlighting previously unresolved parts of the general problem. Certain possibilities of using the Earth remote sensing data for functional estimation of the lands that were changed by anthropogenic activities are carried out in this work. First of all, arable land, with an analysis of the ecological and economic balance of the area based on geoecological coefficients, and then emphasis on the areas that are primarily exposed to ecological risks of exogenous processes and the influence of anthropogenic factors based on geomorphological features using digital terrain models. Measures to improve the ecological stability of agro-landscapes and the landscape-anthropogenic structure of the area's lands are proposed. Hydrographic zoning and catchment areas of Tatarbunars'kyi District were conducted. For one of them - the catchment area of the Karachaus estuary, hydrologic-morphological features were analyzed, and an improved scheme for nature management was developed. The presented cartographic material of the aforementioned components, and despite the fact that the materials of the article are primarily demonstrative and methodological, can be used for further, deeper spatiotemporal assessment of the ecological status of territorial complexes of the region, aimed at developing new management plans for sustainable nature usage.

Formulating the purpose of the article. The purpose of the work is: functional assessment of the ecological status of the economic landscape structure, and development of recommendations for protecting natural territorial complexes of Tatarbunars'kyi District in Odesa region based on the use of GIS and ERS data.

The main tasks aimed at achieving the goal were:

- estimation of ecological parameters (temperature of warming of the territorial complexes, aridity, condition of plant-based biomass), and their interrelation in spatial and temporal dynamics simultaneously in the whole District;

- assessment of the state of nature management and its balance;

- terrain analysis and emphasis on the areas that are primarily the most at environmental risk of exogenous processes and influence of anthropogenic factors;

- hydrographic zoning and measure development for sustainable use of nature, for natural conservation of the catchment area of the Karachaus estuary at the «Tuzlovs'kyi Complex».

Materials and methods. The Landsat8 satellite images with OLI and TIRS sensors [52], as well as $30 \mathrm{~m}$ digital terrain relief models obtained from the international «Shuttle radar topographic mission» (SRTM30), radar image [43] were used as an output. Spatial distribution of the population was carried out on the basis of «OpenStreetMap» data [44], using automatic IDW (inversely-weighted distance) interpolation. Spatial analysis and data processing were performed in QGIS v 3.4.6 software software package with integrated SAGAGIS and GRASSGIS tools, namely: vector and raster data processing, spectral index calculation, morphometric and topographic terrain analysis, hydrographic zoning, density calculation and construction of interpolation surfaces, visualization and design of cartographic materials. Radiometric calibration and atmospheric correction of the Landsat 8 satellite images were carried out on the basis of the use of the additional «SemiAutomatic Classification Plugin» geo-information module also in QGIS v 3.4.6.

To calculate the spectral brightness of distant infrared radiation in a unit of temperature, the values of the calculated coefficients were used according to the calculation method from the metadata file attached to the satellite images [53].

The Normalized Difference Vegetation Index NDVI $[36,38,46]$, which is one of the most common indices for the quantification of vegetation, has been calculated for its main purpose.

The watershed distribution was estimated using the modified Normalized Differential Moisture Index (NDMI), which is derived from the near and short-wave infrared parts of the wavelength spectrum and characterizes the aridity level of landscape complexes [54].

The analysis of land use structure and determination of the anthropogenic load was conducted based on ranking and consolidation of territorial objects into homogeneous groups. The coefficients of anthropogenic transformation of the landscape structure of natural territorial complexes were calculated according to the methodology [11].

LS-factor (length and slope factor) was used to calculate areas with planar erosion potential, which 
combines the influence of the slope and bevel length of the terrain, calculated according to a corresponding methodology based on the digital terrain model [42].

As a basis for the data of remote sensing of the development of recommendations for the catchment basin of the Karachaus estuary, in addition to the relief data, a Sentinel2B satellite image was used [49].

Results and their analysis. One of the most important physical characteristics in environmental studies is the surface temperature, which characterizes the intensity of processes in natural environments and the degree of their homogeneity. An analysis of the temperature distribution of Tatarbunars'kyi District's territorial complexes based on the Landsat8 satellite has revealed a high amplitude of the indicator. For example, according to the Landsat8 (2015.09.22) satellite imagery, the maximum temperature of territorial complexes was $28.50{ }^{\circ} \mathrm{C}$, while the lowest figure was $16.41^{\circ} \mathrm{C}$, the standard deviation of temperature was $3.88^{\circ} \mathrm{C}$, the coefficient of variation of $24 \%$ was fairly homogeneous, mainly due to plowed soils without any vegetation (Fig. 1), a share of which at this date has amounted to $78 \%$ of the total land area of the District. These areas have the highest surface warming (Fig. 2).

In general, the area with the highest frequency distribution of temperature values is found on plowed land and water bodies (Fig. 3).

The amplitude of fluctuations in terrestrial temperature in the territory of the District was $9.81{ }^{\circ} \mathrm{C}$ for the same period of time, meaning that the warming of plowed soil is higher than the warming under plant cover by almost $10{ }^{\circ} \mathrm{C}$ even in autumn, which certainly affects the hydrological, geochemical and biological processes of the area, especially in summer.

The spatial distribution of NDVI over time in the area allowed to detect a significant change of the figure within just one month. For example, the calculation of NDVI on 24.05.2015 has showed that the maximum figures in the range of $0.5-0.81-$ dense plant cover (Table 1) had a land area of $341.66 \mathrm{~km}^{2}$ (Fig. 4), at the end of summer - on 26.08.2015 - lands with maximum index values in the range of $0.5-0.79$ occupied an area of $55.45 \mathrm{~km}^{2}$ (Fig. 5), and a month later plant cover with an index value in the range of more than 0.5 decreased to an area of $13.641 \mathrm{~km}^{2}$ (Fig. 6), which is 25 times more

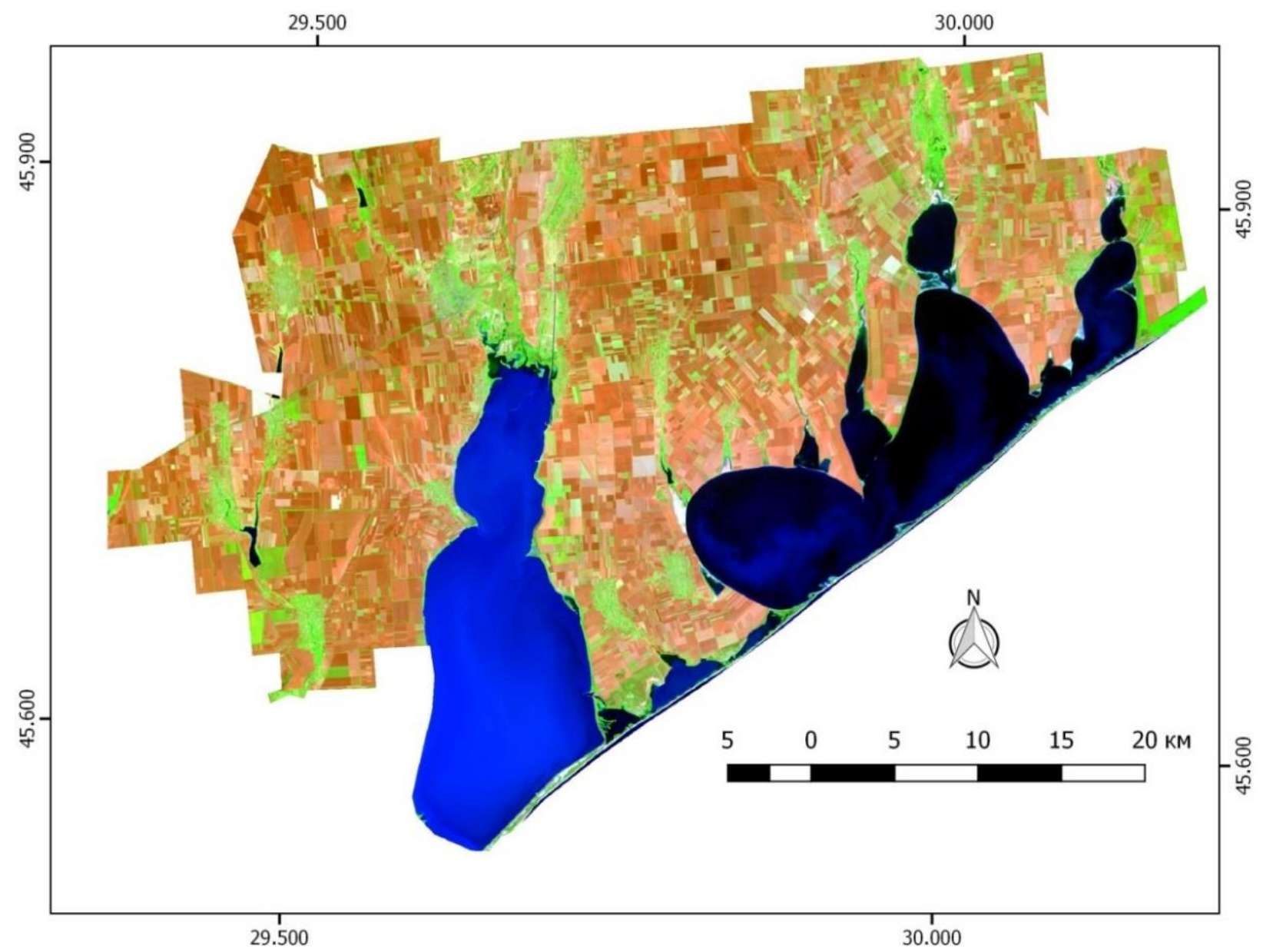

Fig. 1. Color-synthesized image of natural territorial complexes of Tatarbunars'kyi District based on the spectral channels of the Landsat 8 satellite: B7 - average (SWIR-2); B5 - near infrared (NIR); B3 - green; data for 2015.09.22 


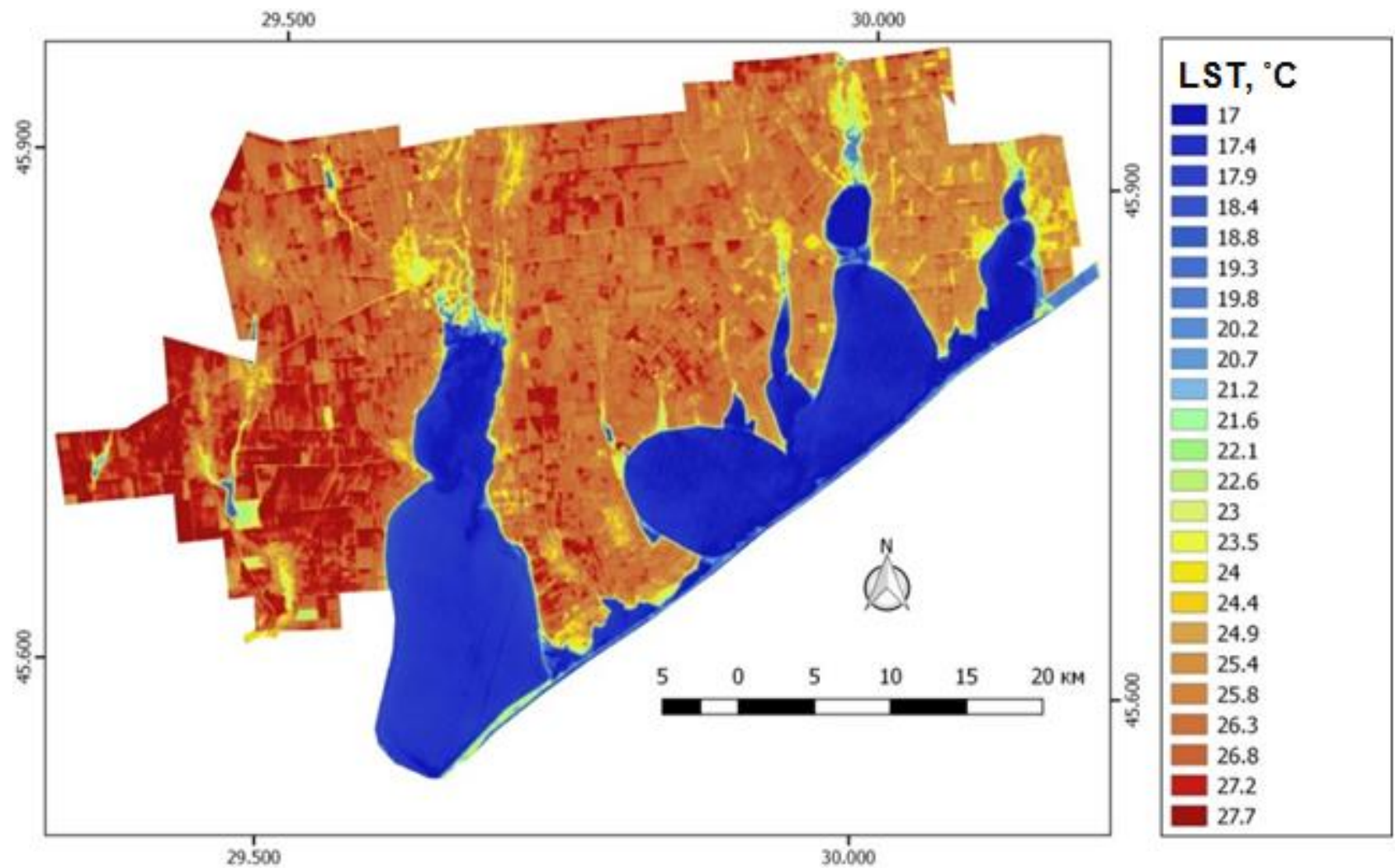

Fig. 2. Land surface temperature (LST) distribution of Tatarbunars'kyi District natural and territorial complexes from 2015.09.22 according to the thermal channel B10 of the Landsat8 satellite

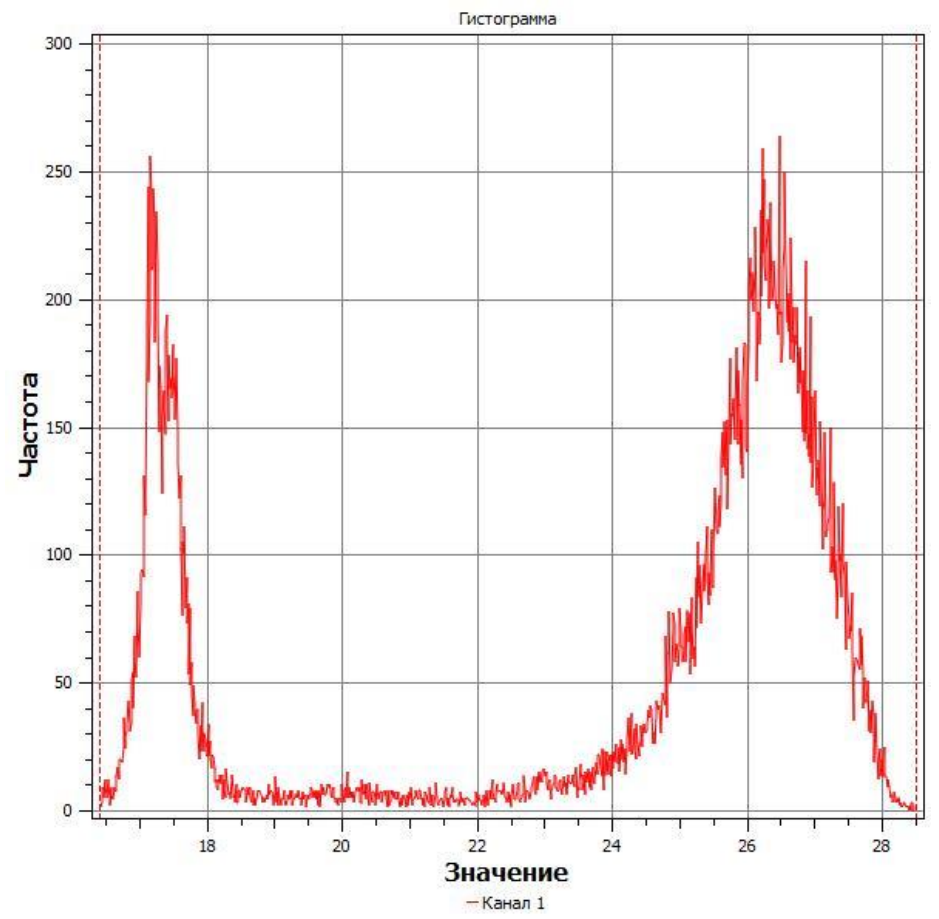

Fig. 3. Histogram of land surface temperature (LST) distribution values of Tatarbunars'kyi District's territorial complexes from 2015.09.22 according to Landsat8

compared to May, which is primarily related to harvesting and the formation of «bare» land in its place.

A characteristic feature of agricultural landscapes, namely arable land, in comparison with other natural territorial complexes (landscapes) is the presence of significant seasonal dynamics of the amount and density of plant biomass, according to the values of the NDVI index, especially in the May-October period. This feature is associated with the process of treatment and cultivation of this type 
of land. However, the corresponding values of plant biomass of other types of land during the same period do not change that significantly (Table 2).

Assessment of the water supply of the territory is an important feature in the field of water management and development of rational water resources usage principles of the region. Spectrozone satellite imaging data, along with field and meteorological studies, provide additional information on soil moisture content and soil cover with the help of, for example, the Normalized Differential Humidity Index (NDMI). High moisture content is inherent in healthy vegetation, which grows faster and is more resistant to fires.

As follows from the distribution of the index on 2015.09.22, its smallest figures are found in plowed soils, the highest figures are found in plant-covered and coastal areas (Fig. 7).
A comparative analysis of raster surfaces of Tatarbunars'kyi District's functional indicators warming, vegetation development, and humidity of territorial complexes, calculated on the basis of the spectroscopic satellite images from 2015.09.22, even visually reveal the correlation between them.

The temperature gradient is at its biggest in areas between the vegetation cover and bare soil, which also indicates the relationship between the plant cover and temperature. For the quantitative characterization of these processes, a test area of arable land in a region with sown and plowed grounds was selected.

The calculation of the correlation relationship between LST surface temperature, the NDVI vegetation index, and the NDMI moisture index showed a statistically significant correlation (Fig. 8).

Table 1

NDVI index figures for different objects [36]

\begin{tabular}{|l|l|l|}
\hline Type of land cover & NDVI (scale from -1 to 1$)$ & NDVI (scale from: 0 to 255$)$ \\
\hline Dense vegetation & $0.500<=$ NDVI $<=1$ & $210<=$ NDVI $<=255$ \\
\hline Sparse vegetation & $0.140<=$ NDVI $<0.500$ & $118<=$ NDVI $<210$ \\
\hline Poor vegetation & $0.090<=$ NDVI $<0.140$ & $105<=$ NDVI $<118$ \\
\hline Bare land & $0.025<=$ NDVI $<0.090$ & $88<=$ NDVI $<105$ \\
\hline Clouds & $0.002<=$ NDVI $<0.025$ & $83<=$ NDVI $<88$ \\
\hline Snow and ice & $-0.046<=$ NDVI $<0.002$ & $70<=\mathrm{NDVI}<83$ \\
\hline Water & $-1<=\mathrm{NDVI}<-0.046$ & $0<=\mathrm{NDVI}<70$ \\
\hline
\end{tabular}
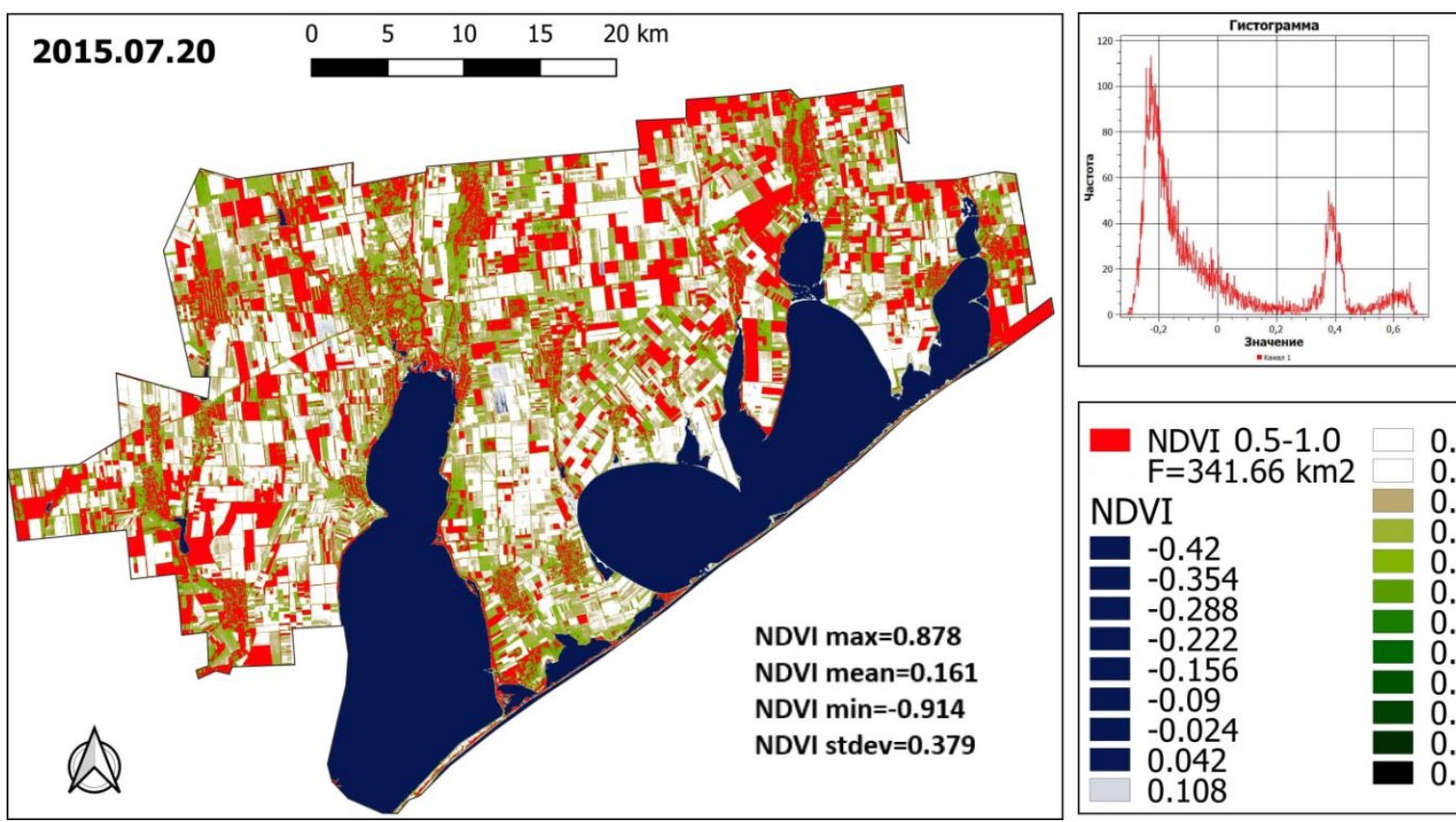

\begin{tabular}{|l|l|}
\hline NDVI $0.5-1.0$ & 0.174 \\
F=341.66 km2 & 0.24 \\
NDVI & 0.306 \\
-0.42 & 0.372 \\
-0.354 & 0.438 \\
-0.288 & 0.504 \\
-0.222 & 0.57 \\
-0.156 & 0.636 \\
-0.09 & 0.702 \\
-0.024 & 0.768 \\
0.042 & 0.834 \\
0.108 & 0.9 \\
\hline
\end{tabular}

Fig. 4. Distribution of NDVI index on the territory of Tatarbunars'kyi District from 20.07.2015 


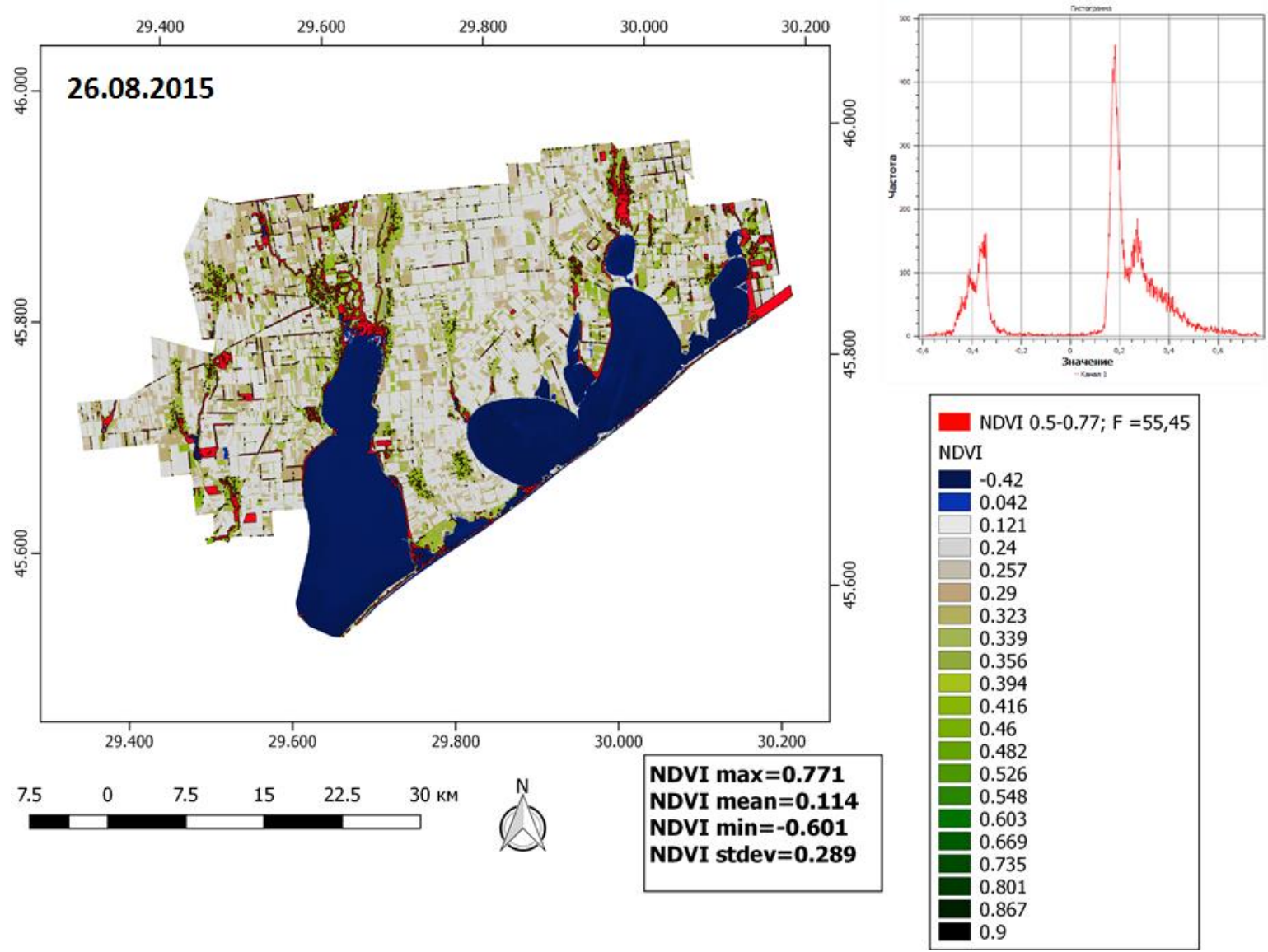

Fig. 5. Distribution of NDVI index on the territory of Tatarbunars'kyi District from 26.08.2015

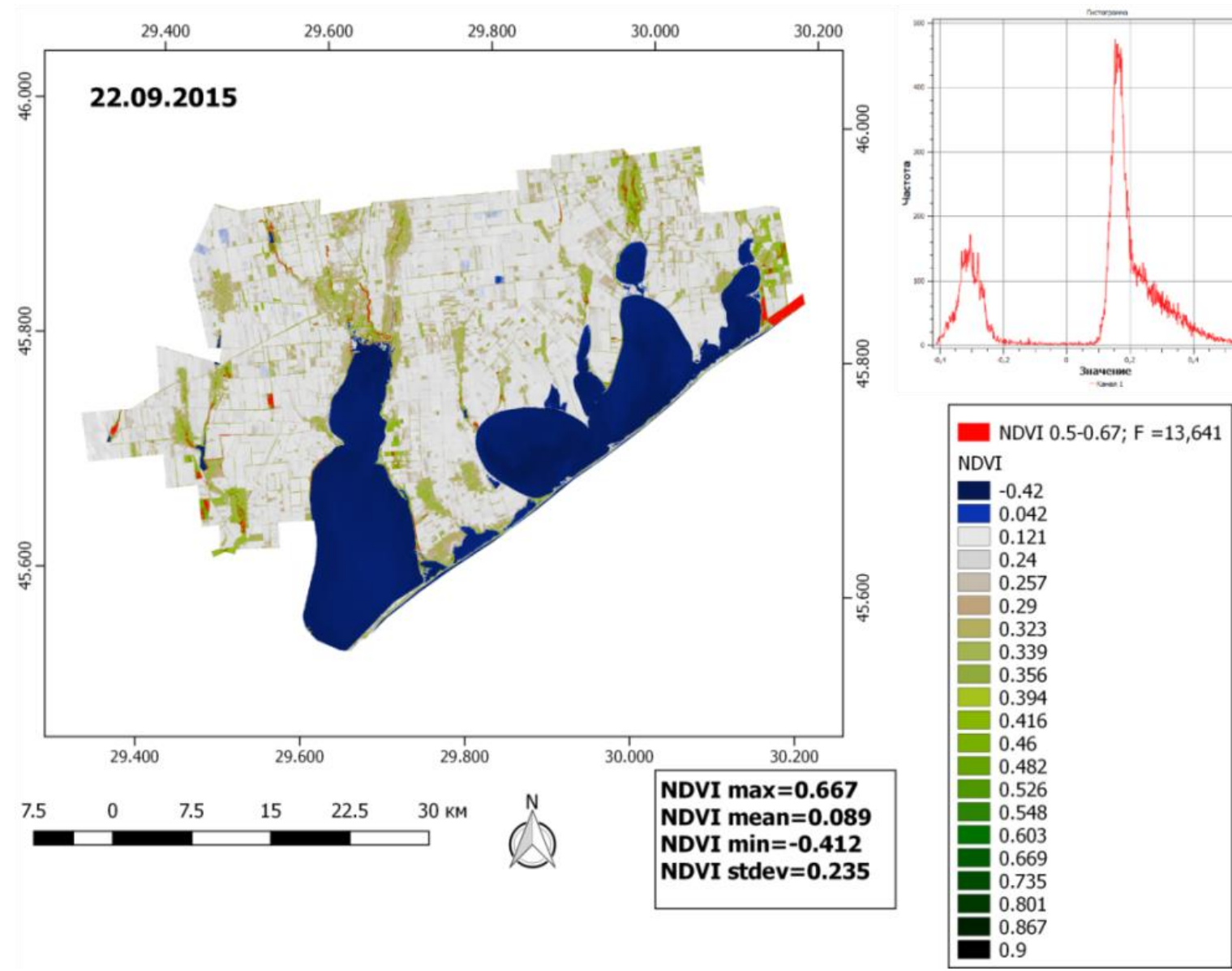

Fig. 6. Distribution of NDVI index on the territory of Tatarbunars'kyi District from 22.09.2015 
NDVI index figures for Tatarbunars'kyi District

\begin{tabular}{|l|l|l|l|l|l|l|l|l|l|}
\hline \multirow{2}{*}{ Type of land } & \multicolumn{3}{|c}{2015.05 .24} & \multicolumn{3}{c|}{2015.07 .20} & \multicolumn{3}{c|}{2015.09 .22} \\
\cline { 2 - 10 } & Mid. & Max. & Min. & Mid. & Max. & Min. & Mid. & Max. & Min. \\
\hline Arable land & 0.57 & 0.81 & 0.11 & 0.51 & 0.77 & 0.08 & 0.14 & 0.69 & 0.05 \\
\hline Meadows & 0.53 & 0.79 & 0.40 & 0.46 & 0.70 & 0.31 & 0.33 & 0.56 & 0.22 \\
\hline Reed beds & 0,57 & 0.81 & 0.43 & 0,58 & 0.79 & 0.50 & 0.42 & 0.62 & 0.31 \\
\hline Forests & 0.75 & 0.81 & 0.53 & 0.74 & 0.81 & 0.49 & 0.55 & 0.64 & 0.34 \\
\hline
\end{tabular}
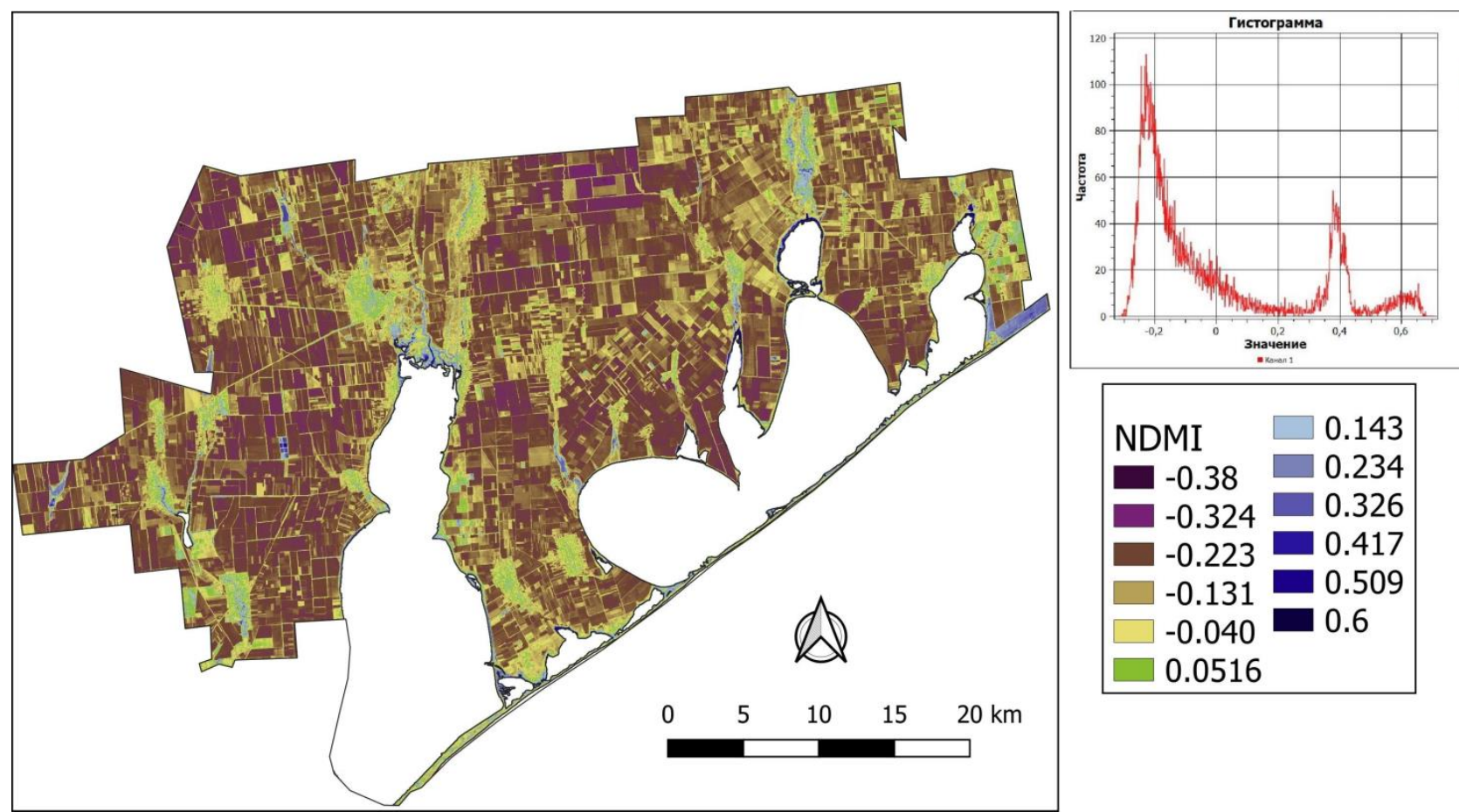

Fig. 7. NDMI Index Distribution for Tatarbunars'kyi District from 2015.09.22 according to Landsat8

In terms of the coefficient of determination $\left(R^{2}\right)$ between these characteristics, the distribution of values is the most dense for plowed soils. The distribution of isotherms indicates the largest gradient in the boundary zone between soils and the vegetation cover.

Analysis of the land use structure on the territory of Tatarbunars'kyi District, according to the ecological passport of the Odesa region [8], has showed that, in general, its territory is characterized by a large area of the nature reservation fund (Fig. 9), due to wetlands of the «Tuzlovs'kyi complex»unique coastal estuarine and lagoon water bodies formed under the influence of transgression of the sea in the geological past.

The percentage of NRFs (nature reservation funds) in the region is at $16.5 \%$ (including both land areas and water bodies), while in the majority of administrative regions of the Black Sea NRF facili- ties are either completely absent, or make up less than $2 \%$.

Despite the significant percentage of the total area of NRF objects and the Ramsar wetlands of international importance, which form the econetwork of the Odesa region, the land use structure of the area is extremely unbalanced. A large part of the District's territories is occupied by arable land $61.44 \%$, or $81.61 \%$ solely of the land area (Table 3), however, more than $4 \%$ of them completely degraded. Such land use structure of the area is unbalanced, since "In case of a violation of sustainable environmental ties by more than $40 \%$ the system depreciates and degrades» [16].

In accordance with the methodology [11], and the classification of land by the degree of anthropogenic load (AL), coefficients of anthropogenic transformation of the territory (Table 4), which characterize the ecological economic balance (EEB) of the 

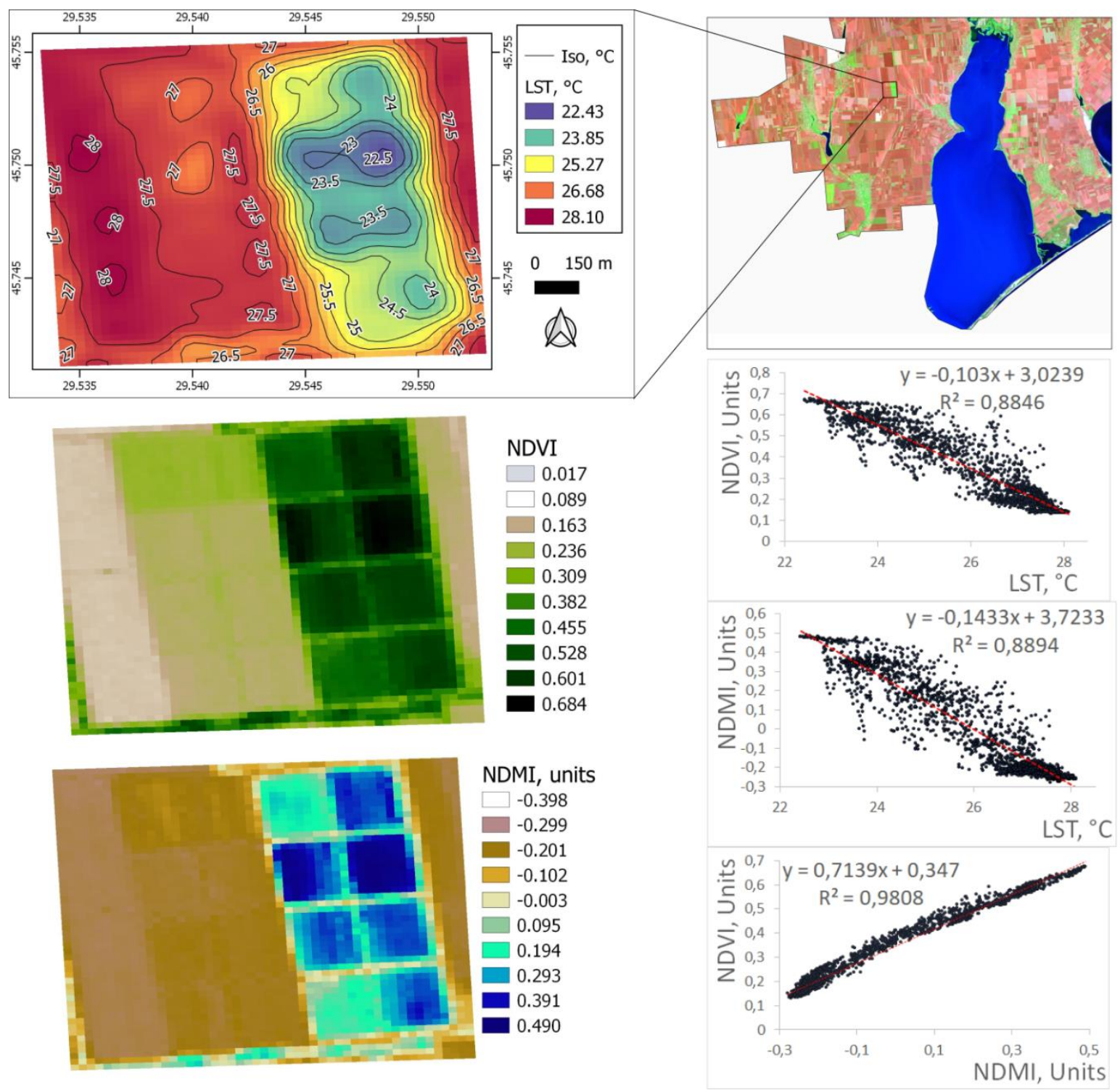

Fig. 8. Distribution of LST surface temperature, NDVI vegetation index and NDMI moisture index in the tested arable land in Tatarbunars'kyi District with sown and plowed land from 2015.09.20 according to Landsat8

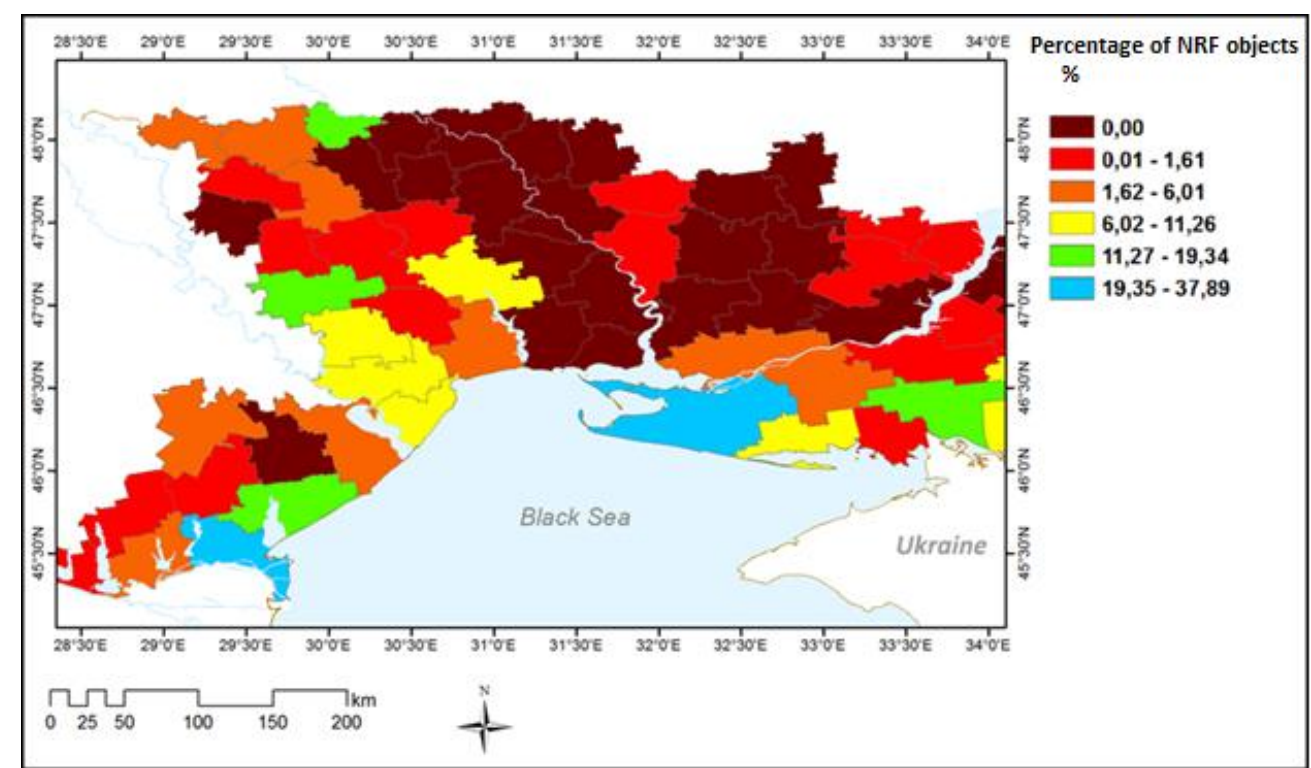

Fig. 9. Percentage of objects of the nature reservation fund in the northwestern administrative regions of the Black Sea (according to their ecological passports) 
Both land and water bodies structure of Tatarbunars'kyi District

(according to ecological passports and satellite measurements)

\begin{tabular}{|c|c|c|c|}
\hline \multirow[b]{2}{*}{ The name of the objects } & \multirow{2}{*}{$\begin{array}{l}\text { Area, } \\
\text { thousand ha }\end{array}$} & \multicolumn{2}{|c|}{ Percentage, $\%$} \\
\hline & & Including water bodies & $\begin{array}{c}\text { Not including water } \\
\text { bodies }\end{array}$ \\
\hline General area & 174.30 & 100.00 & 100.00 \\
\hline NRF objects (reserve lands) & 5.45 & 3.13 & 4.16 \\
\hline Foresrs under the NRF & 0.54 & 0.31 & 0.41 \\
\hline Ater bodies under the NRF & 22.90 & 13.13 & - \\
\hline Other water bodies & 20.21 & 11.59 & - \\
\hline Reed beds and wetlands & 3.18 & 1.82 & 2.42 \\
\hline Forests & 3.60 & 2.06 & 2.74 \\
\hline Pastures, hayfields & 5.40 & 3.10 & 4.12 \\
\hline Recreational areas & 0.10 & 0.06 & 0.08 \\
\hline Coastal protection lanes & 0.27 & 0.15 & 0.21 \\
\hline Perennial plantings & 0.62 & 0.36 & 0.47 \\
\hline Sandy open lands & 0.74 & 0.43 & 0.56 \\
\hline Arable grounds with degraded land & 4.28 & 2.46 & 3.26 \\
\hline Arable land & 102.80 & 58.98 & 78.35 \\
\hline Area of domestic solid waste (DSW) & 0.059 & 0.03 & 0.04 \\
\hline Urban settlements & 2.85 & 1.64 & 2.17 \\
\hline Rural settlements & 1.37 & 0.79 & 1.04 \\
\hline
\end{tabular}

Table 4

Calculation of ecological and economic balance coefficients for Tatarbunars'kyi District

\begin{tabular}{|l|c|c|}
\hline \multirow{2}{*}{ Geoecological coefficients of the EEB } & \multicolumn{2}{|c|}{ Territory of the District } \\
\cline { 2 - 3 } & Including water bodies & Land only \\
\hline Absolute pressure coefficient (Ka) & 0.30 & 1.35 \\
\hline Relative pressure coefficient (Kr) & 1.77 & 5.59 \\
\hline $\begin{array}{l}\text { Area of land with resource-stabilizing functions (RSF, } \\
\text { thousand ha) }\end{array}$ & 68.66 & \\
\hline Natural protection ratio (Knp) & 0.39 & 29.66 \\
\hline
\end{tabular}


territory of Tatarbunars'kyi District, were calculated.

The calculation of ecological and economic balance coefficients of the territory of Tatarbunars'kyi District has also showed the lack of balance, and low environment-protective function of the ecological structure of the territorial complexes.

High values of the relative pressure coefficient $\mathrm{Kr}$ (more than 1), indicate the ecological and economic imbalance of the territory. From the absolute pressure coefficient $\mathrm{Ka}$ it can be concluded that the number of anthropogenically transformed lands in relation to nature conservation and unused land is much smaller. The natural protection ratio $\left(\mathrm{K}_{\mathrm{np}}\right)$ of the catchment area is low - less than 0.5, which, according to the methodology, indicates a critical level of the territory's protection [11].

Ecological parameters of a balanced territorial organization in the steppe zone

\begin{tabular}{|l|c|c|}
\hline \multicolumn{1}{|c|}{ Exponent } & Limit value, $\%$ & Optimal value, $\%$ \\
\hline Natural landscapes & no less than $35-40[23]$ & no less than 60 [30] \\
\hline Arable land & no more than 60 [24] & $40-45[24,30]$ \\
\hline Perennial grasses from an arable area & no less than 30 [13] & $30-50[13]$ \\
\hline Forest plantations & $10-15[21]$ & $15-20[21]$ \\
\hline $\begin{array}{l}\text { Field protection forest lanes from an arable } \\
\text { area }\end{array}$ & $4-5[19]$ & $7-10[19]$ \\
\hline Irrigated land from a farmland area & Up to 15 in an arid zone [22] & $10[22]$ \\
\hline Residential areas & no more than 10 [23, 24] & $1-3[13]$ \\
\hline
\end{tabular}

Based on the analysis of the geomorphological features of Tatarbunars'kyi District, which stipulate geochemical flows of terrigenous matter transfer, soil erosion, and other processes, sections with a slope of more than $3^{\circ}$ have been highlighted using SRTM30 digital terrain models, which, according to literary data [15], are at the greatest ecological risk of exogenous processes and influence of anthropogenic factors (Fig. 10).

The location of such sites is inherent in the ridge-girder structures, river valleys and slopes of the estuaries. These areas are recommended to be used in the «natural» state (hayfields, pastures, perennial plantations, recreation and tourism areas) with the removal of arable lands. By their location, almost all of them are part of coastal protection lanes and lands of the water fund in accordance with the Water Code of Ukraine [4], where a full project documentation hasn't been developed yet. From the point of view of ecological and economic balance of the territory, it is most expedient to carry out an in-
The formation of sustainable ecological infrastructure requires improvement of the land management structure in accordance with the criteria of ecological and economic balance (Table 5).

On arable land, it is recommended to increase the protective forest cover of the territory by supplementing the existing network of nature-protective forest lanes. The optimum length between forest strips in the southern black earths should be no more than $400 \mathrm{~m}$, with an area of up to $60-70$ ha on a plateau and up to 30 - 40 ha on a slope. It is advisable to move away from the practice of creating fields with an area of $150-200$ hectares or more, where the role of biological regulating mechanisms of field protective lanes is poorly noticeable $[3,15]$.

Table 5

ventory of landscape and economic structure, especially in these areas, with their submission to cadastral schemes and land management plans, with the formation of an appropriate environmental regime.

The distribution of settlements and population density in Tatarbunars'kyi District indicates that a large number of them are located precisely on the grounds of river valleys and in places with a slope of more than $3^{\circ}$ (Fig. 11), which also leads to intensification of exogenous processes and pollution of water bodies. The aggravating fact is that many of them do not have a centralized sewer system. In general, the territory is characterized by the absence of large cities and low population density.

Another approach to forming a balanced land use structure, ecological network, and sustainable development of the area is hydrographic zoning. According to the requirements of the EU Water Framework Directive [37], which are currently being implemented in national legislation, management of the ecological status of water bodies is 
based on a basin approach with the development of appropriate management plans and the formation of basin management administration. Small rivers, catchment parts of the Tuzlovs'kyi complex, the Sasik estuary, etc. are located on the District's territories (Fig. 12).

For further hydrologic morphometric analysis and development of environmental measures, a Karachaus catchment area was selected (a subsidiary estuary with a developed gully-girder system) from the Tuzlovs'kyi complex, within the boundaries of the District. Current capabilities of GIS analysis have made it possible to calculate a number of hydrologically-morphological indicators of the catchment area (Fig. 13), which allow to determine places of the greatest manifestation of exogenous and anthropogenic processes (slope sites, direction and intensity of surface runoff, displays of linear and planar erosion).

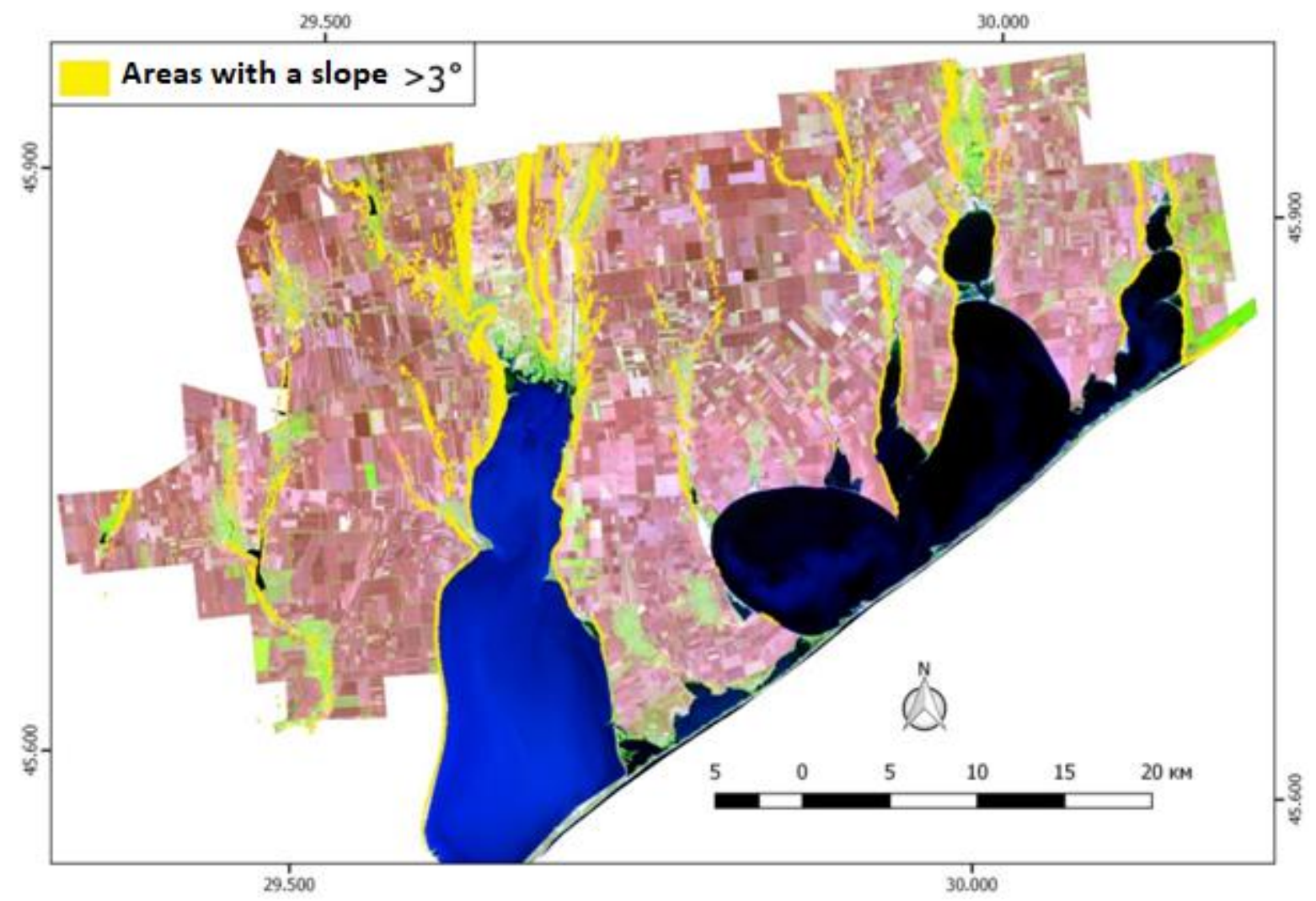

Fig. 10. The distribution of sites with $\mathrm{a} \geq 3^{\circ}$ slope on the territory of Tatarbunars'kyi District according to SRTM30 digital terrain models superimposed over a Landsat8 satellite image from 22.09.2015

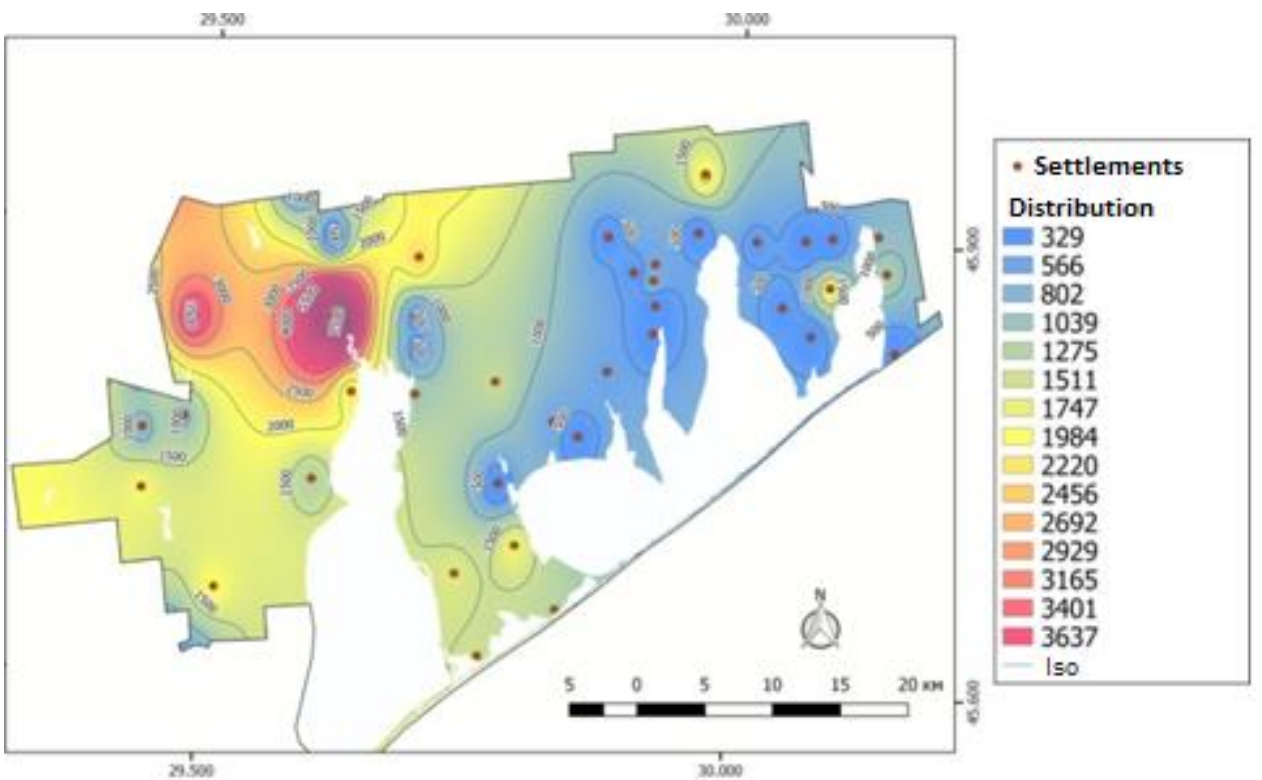

Fig. 11. Population density distribution in Tatarbunars'kyi District, built according to OpenStreetMaps data in the QGIS software package 


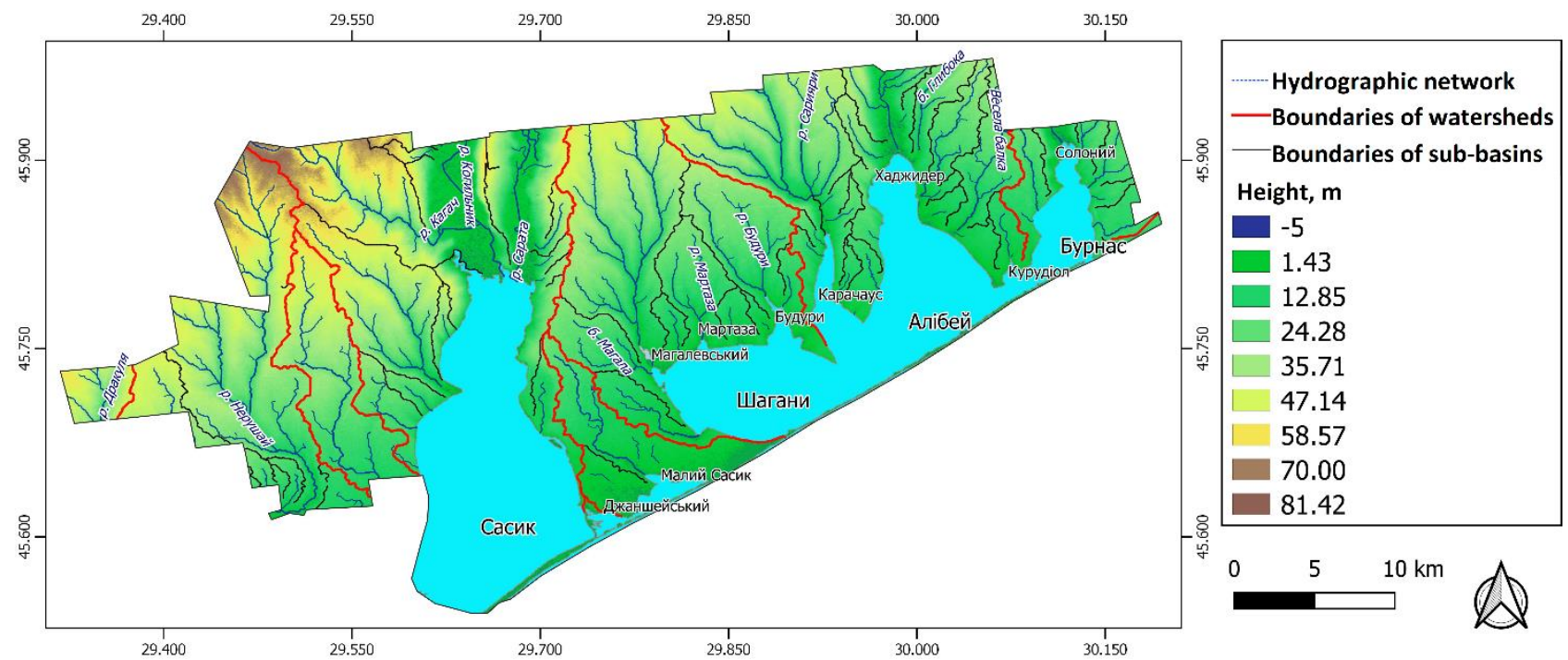

Fig. 12. Hydrographic network of Tatarbunars'kyi District and its watershed boundaries

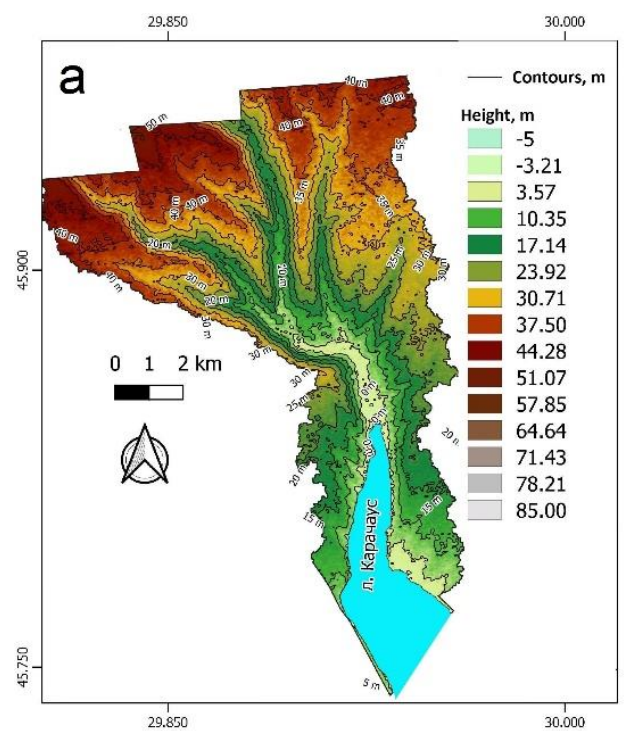

d

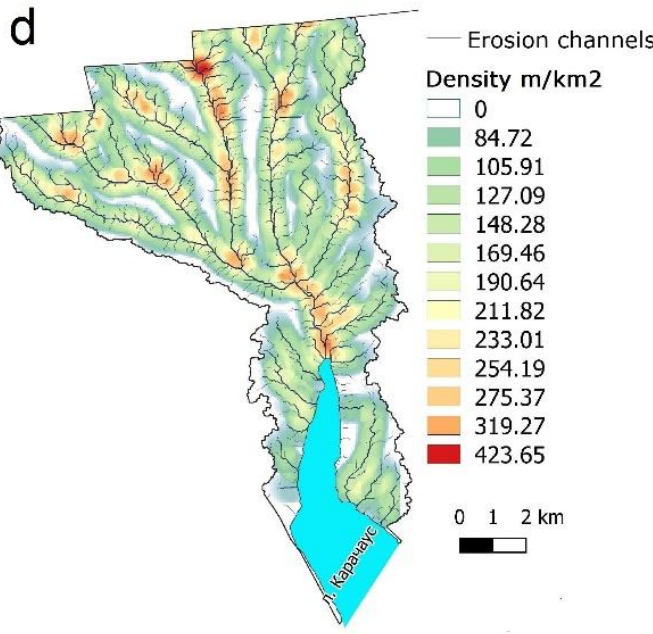

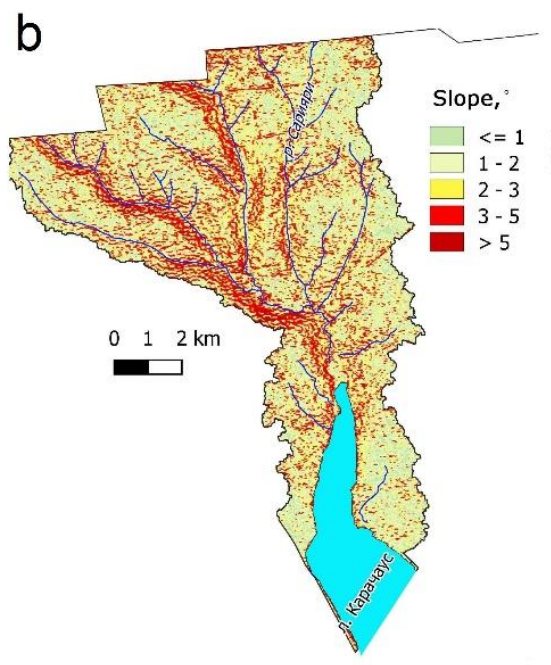
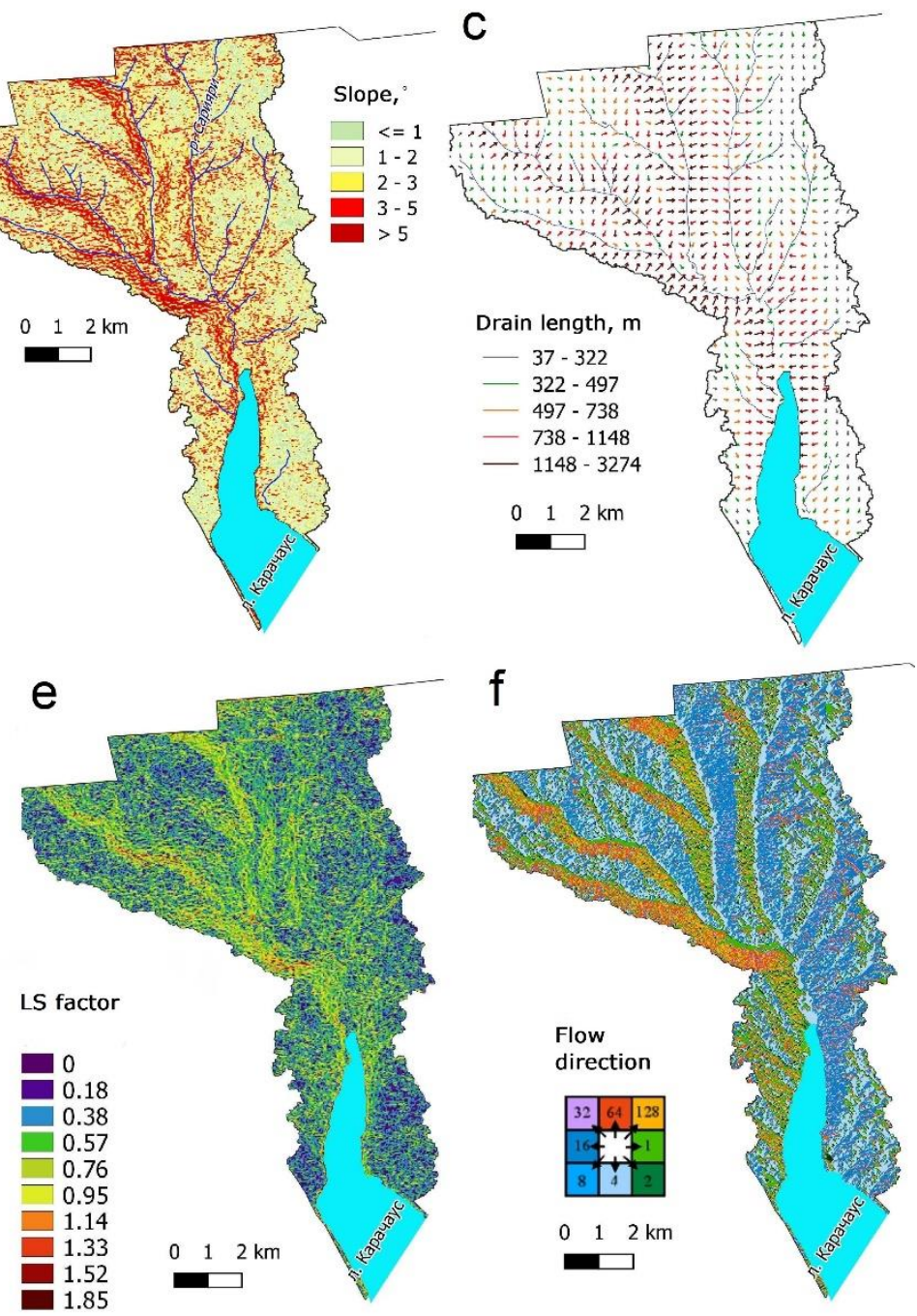

Fig. 13. Hydrologic and morphological features of part of the catchment area of the Tuzlovs'kyi estuary complex within the borders of Tatarbunars'kyi District: $\mathrm{a}$ - terrain heights; $\mathrm{b}$ - biases; $\mathrm{c}$ - flow vectors; $\mathrm{d}$ linear erosion structures and density; $\mathrm{e}$ - the risk of plane erosion; $\mathrm{f}-$ the drain direction of each raster cell

As evidenced by careful hydrologic morphological analysis, this area does not imply widespread intensive use of nature, as it has a developed gullygirder system and terrain fragmentation. It is clear 
that environmental management in such conditions must be differentiated in spatial, intensity-based, landscape and settlement-balanced terms, taking the functions of the ecological network into account. Moving on to the proposed sustainable environmental management measures for the further development of an ecological management plan, one should also mention the legally stipulated environmental measures for the water fund lands, and their introduction into nature, especially the nature protection lanes (NPLs) along the watercourses. The principles of their establishment, structure and nature protection regime are determined in accordance with the law of direct action in this field - Water Code of Ukraine (Articles 88-90), which includes NPLs along watercourses, NPLs along seas and estuaries (with beach area allocations) [4].
At present, nature management in the form of ubiquitous plowing of land, unauthorized rural settlement development on the territory of the catchment area is conducted without taking terrain and gully-girder structure into account, without observing agro-technical land protection norms, resulting in both deep and planar erosion (Fig. 14 a), in addition to that, windbreaks are not enough to protect against wind (deflation), and water erosion of soils, as well as the associated reduction of the ecological status of water bodies. Given the hydrological and morphological conditions, state of the lands, regulation of watercourses and environmental legislation, it is proposed to reorient the structure of land use, to increase the number of environmental protection areas, to allocate sites with extensive form of land use, which is certainly going to be ecologically beneficial (Fig. 14 b).
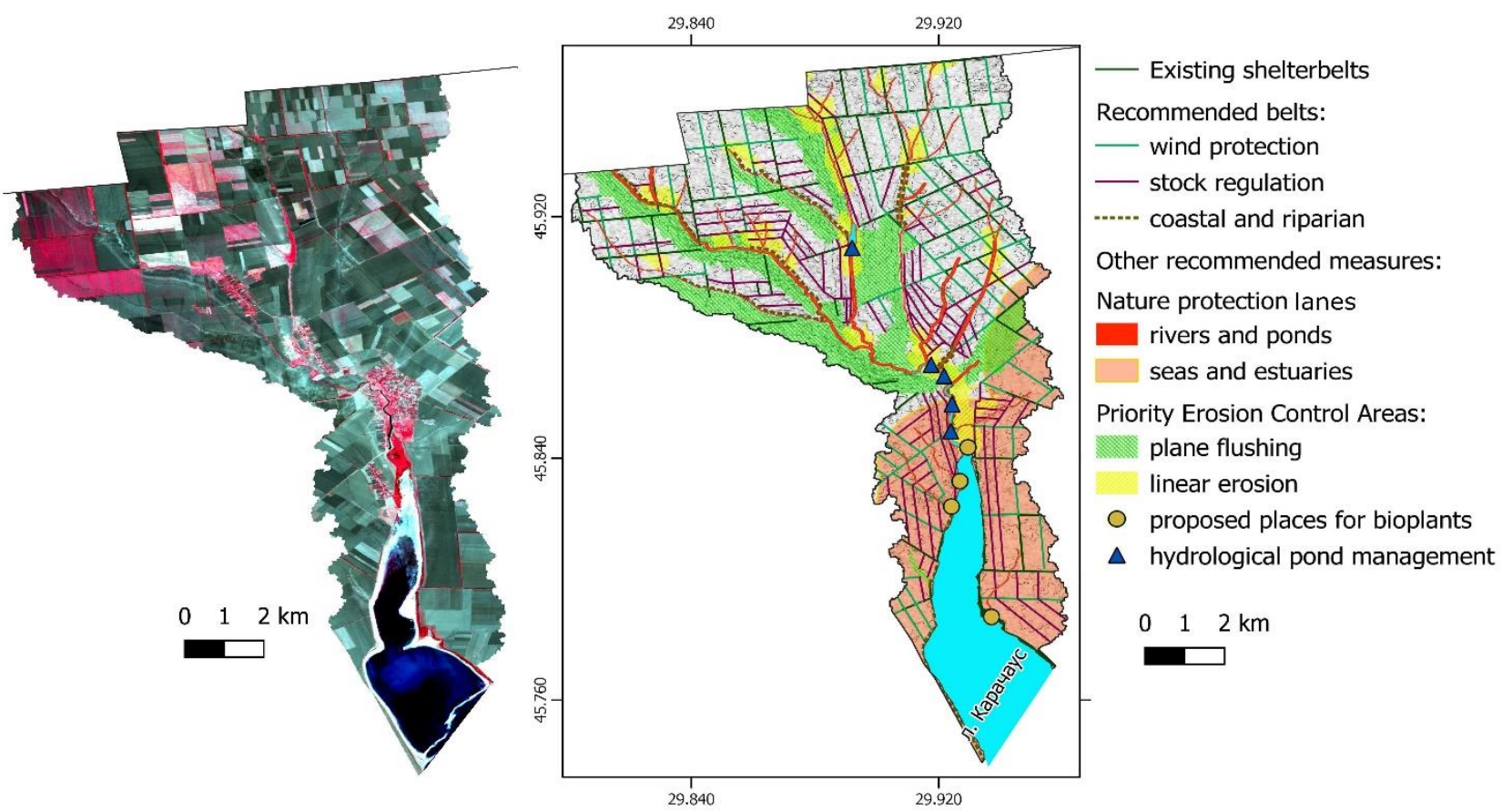

Fig. 14. The existing and recommended structure of land use of the Karachaus catchment area within the boundaries of Tatarbunars'kyi District: a - full-color satellite Sentinel2B image from 2019.09.15 from the combination of NIR-Green-Blue channels (vegetation is red); $b-a$ scheme of reclamation and environmental measures (management plan at its first approximation) [49]

First of all, it is necessary to transfer the water fund lands to the «nature» of applying them to land management plans of settlements and land cadasters. Furthermore, proper agro-technical measures were not met throughout the whole District, among other things agricultural territories are insufficiently countered by protective windbreaks. The existing structure of windbreaks consists of $80.9 \mathrm{~km}$, about one third of the fields do not have any windbreaks at all, the distance between the windbreaks is $1 \mathrm{~km}$ on average, the corresponding edging area - 200 ha. This windbreak structure does not fulfill its environmental function, so it is recommended to in- crease it by 3 times. At the same time it should at least include additional wind protection $(92.1 \mathrm{~km})$, stock regulation $(124.7 \mathrm{~km})$, coastal and riparian $(30.8 \mathrm{~km})$. Additional windbreaks were plotted as follows: windproof, taking into account prevailing wind directions with a cell size of 500 per $1000 \mathrm{~m}$; stock regulation windbreaks were placed on slope sections along the horizontal lines at a distance of $400-300 \mathrm{~m}$, depending on the slope; coastal and riparian windbreaks along eroded girders $3-5 \mathrm{~m}$ from the shorelines. As a prevention of land erosion spread, it is also recommended that some of them (on the slopes of gully-girder systems) carry out 
sedimentation, conservation, and exploitative reorientation (use in a quasi-natural state - perennial crops, pastures, hayfields, etc.). In order to control the quality and colmatage (mudding) of the organized runoff of ravines and girders, it is proposed to create biological filters in their mouths along the estuary - biological plateaus (artificial ecosystems with sinusoidal filtration biocenoses). Small local rivers from the basin were basically destroyed as a result of a rupture of the hydrographic network and pond overregulation. It is recommended to either completely eliminate unauthorized ponds, or to allow their operation solely in case of proper environmental documentation and operating modes depending on the water content of the year.

It is advisable to use arable land on planar grounds and based on the principles of adaptive agriculture, with the introduction of soil protective crop rotations and the use of unconventional agrotechnical measures (minimization of soil cultivation, optimization of rotation, improved irrigation systems etc.).

\section{Conclusions}

The results of GIS thermal channels analysis of Landsat 8 satellite images revealed a significant amplitude of temperature fluctuations of Tatarbunars'kyi District's territorial complexes. The warming of plowed soil is higher by $10{ }^{\circ} \mathrm{C}$ than under plant cover in the summer period, which certainly influences the hydrological, geochemical and biological processes of the area at the current level of agricultural development of arable land.

The distribution of vegetation dynamics by NDVI across the area revealed a significant value change seasonally and even within one month. Territories with the maximum index values corresponding with the dense vegetation cover occupied an area of $341.66 \mathrm{~km}^{2}$ on May 24, 2015, at the end of summer - August 26, 2015, - $55.45 \mathrm{~km}^{2}$ respectively, and a month later the area of vegetation in this index range decreased to $13.64 \mathrm{~km}^{2}$, which is more by 25 times compared to May, primarily due to harvesting and tillage in the form of arable land.
The calculation results of the complex geoecological indicators also showed ecological imbalance of the lands' structure. Irrational farming has led to degradation of the hydrographic network of small rivers in the area, formation of soil erosion, trenching, reduction of the ecological status of water bodies, including nature protection areas with an international status of Ramsar lands.

The distribution of settlements and population in Tatarbunars'kyi District indicates that a large number of them are located on the grounds of river valleys and in places with a slope of more than $3^{\circ}$, which also leads to intensification of exogenous processes and pollution of water bodies.

Management plan of the Karachaus estuary (its first approximation), which is developed on the basis of a hydrologic morphological analysis of the catchment area and land use structure, includes the application of natural protection lanes to the settlements' land management plans and land cadasters, conducting appropriate agro-technical measures, particularly increasing the length of the windbreak system by 3 times with their respective functional purpose. As a prevention of land erosion spread, it is also recommended that some of them (ones on the slopes of gully-girder systems) carry out sedimentation, conservation and operational reorientation (use in a quasi-natural state - perennial crops, pastures, hayfields, etc.). For the possibility of quality control and mudding of the organized runoff, it is proposed to create biological filters (bio-plateaus) in the mouths along the estuary. It is recommended to either complete eliminate unauthorized ponds, or to operate them solely in case of proper environmental documentation and operating modes depending on the water content of the year. Placement and use of arable land is proposed to be based on the principles of adaptive agriculture.

The result of the GIS assessment is geoinformation databases in the form of raster and vector layers that can be used by executives and other stakeholders for further development of the sustainable development strategy of Tatarbunars'kyi area.

\section{References}

1. Актуальные проблемы лиманов северо-западного Причерноморья: Коллективная монография [Текст] / под ред. Тучковенко Ю. С., Гопченко Е. Д. - Одесса: ТЭС, 2011. - 224 с.

2. Андреев С.М. Метод оценки плодородия почв по материалам космических съёмок (на примере Татарбунарского района Одесской области) [Текст] / С.М. Андреев, Г.Я. Красовский, В.В. Соловей // Ученые записки Таврического национального университета им. В.И. Вернадского. Серия География 2011. - Том 24 (63). №3. - C. 16-23.

3. Балакай Г.Т. Приёмы повышения биопродуктивности земель, сохранения почвенного плодородия и экологической устойчивости агроландшафтов [Текст] / Г.Т. Балакай, Н.И. Балакай, Е.В. Полуэктов, А.Н. Бабичев, Л.А. Воеводина, Л.И. Юрина. - Новочеркасск, 2011. - 71 с.

4. Водний Кодекс Украӥни із змінами і доповненнями, внесеними Верховною Радою Украӥни від 09.04.2014 за 1193-VII (1193-18) [Текст]. - K., 2014. - 38 c. 
5. Гладун Г. Б. Адаптивно-ландшафтні принципи застосування полезахисного лісорозведення в Одеській області [Електронний ресурс] / Г. Б. Гладун, Ю. Г. Гладун, Л. В. Стеревська // Агрохімія $і$ трунтознавство. 2014. - Bun. 81. - C. 59-65. - Режим docmyny: http://nbuv.gov.ua/UJRN/agrohimigrn_2014_81_10

6. Горун В.В. Комплексная оценка рекреаџионного потенциала административньх районов Одесской области [Текст] / В.В. Горун, Г.П. Пилипенко, О.И. Цуркан // Krajobraz i turystyka w warunkach zrownowazonego rozwoju. Landscape and tourism in a sustainable develophent. Kielce-Sobkow, 5-7 lipca, 2012. - C. 55-57.

7. Донеи, В.В. Создание полевого спектрального аппаратурно-программного комплекса для подспутниковой валидации дистанциионного исследования растительности [Текст] / В.В. Донеи, С.М. Кочубей, В.А. Яиенко, Т.А. Казанцев, В.В. Бровченко // Системи обробки інформації. - 2013. - Т. 8, № 115. - С. 36-42.

8. Екологічний паспорт регіону за 2018 рік. [Електронний ресурс]. Режим доступу: http://ecology.odessa.gov.ualekologchnij-pasport-regonu/

9. Использование космической съемки при анализе теплового поля исторической части г.Киева [Текст] / В.E. Филиппович, В.И. Лялько, С.А. Станкевич Г.Б. Крилова, А.Г. Мичак // Проблеми та досвід інженерного захисту урбанізованих територій і збереження спадщчни в умовах геоекологічного ризику / Під ред. В.М. Шестопалова, М.Г. Демчишина, В.О. Кендзери, Ю.О. Маслова / Наукове видання. - К.: Фенікс, 2013. - VI. - С. 64-69.

10. Кочубей С.М. Аппаратура и методы дистанционного зондирования растительности в оптическом диапазоне [Текст] / С.М. Кочубей // Космическая наука и технология. - 2002. - Т. 8, № 2/3. - С. 271-275.

11. Кочуров Б.И. Геоэкология: экодиагностика и эколого-хозяйственный баланс территории [Текст] / Б.И. Кочуров. - Смоленск: СГУ, 1999. - 154 с.

12. Лялько В.І. Багатоспектральні методи дистаниійного зондування землі в задачах природокористування [Текст] / В.І. Лялько, М.О. Попов. - Київ: Наукова думка, 2006. - 360 с.

13. Макевнин С.Г. Охрана природы [Текст] / С.Г. Макевнин, А.А. Вакулин. - Агропромиздат. - М., $1991 .-127$ с.

14. Мінічева Г. Г. Оиінка природної стійкості лиманів Північно-західного Причорномор'я відповідно до принципів водної директиви ЄС [Електронний ресурс] / Г. Г. Мінічева, С. В. Соколов // Наукові доповіді Національного університету біоресурсів і природокористування Украӥни. - 2014. - № 5. - Режим доступу: http://nbuv.gov.ua/j-pdf/Nd2014_5_7.pdf

15. Мухин Ю. П. Устойчивое развитие: экологическая оптимизачия агро- и урболандиафтов: Учеб. пособие [Текст] / Ю. П. Мухин, Т. С. Кузьмина, В. А. Баранов. - Волгоград, 2002. - 127 с.

16. Одум Ю. Основы экологии [Текст] / Ю. Одум. - М.: Мир, 1975. - 740 с.

17. Попова О. Л.Екодіагностика природо-господарської організації території України: агроландшафтний аспект [Електронний ресурс] / О. Л. Попова // Економіка і прогнозування. - 2012. - № 3. - C. 92-101. - Режим доступy: http://nbuv.gov.ua/UJRN/econprog_2012_3_9

18. Попов, М.О. Оиінювання характеристик зелених насаджень з використанням засобів дистанційного зондування Землі [Текст] / М.О. Попов, І.Д. Семко // Основи природокористування та безпека життєдіяльності. - 2013. - Bun. 12. - C. 51-62.

19. Попова О.М. Морфометрія та топонімія гідрологічних об 'єктів національного природного парку «Тузловські лимани» [Текст] / О.М. Попова // Вісник ОНУ. Серія геогр. та геол. науки. - 2016. - 21, - вип. 2 (29). - С. 64-84.

20. Попова О.М. Природно-заповідний фонд Одеської області в системі фізико-географічного районування Украӥни і шляхи його оптимізації [Електронний ресурс] / О.М. Попова // Вісник Одеського національного університету. Серія : Географічні та геологічні науки. - 2017. - T. 22, Вип. 2. - С. 29-47. - Режим достуny: http://nbuv.gov.ua/UJRN/Vonu_geo_2017_22_2_4

21. Парамонов Е. Г. Кулундинская степь: проблемы опустынивания [Текст] / Е.Г. Парамонов, Я. Н. Ииутин, А. П. Симоненко. - Барнаул: Алт. ун-т, 2003. - 138 с.

22. Парфенова Н.И. Энергетические природно-зональные показатели и перспектива их применения в мелиораuии [Текст] / Н.И. Парфенова, Н.М. Решеткина // Мелиорация и водное хозяйство. - 1993. - № 1. - С. 3-5.

23. Реймерс Н. Ф. Особо охраняемые природнье территории [Текст] / Н. Ф. Реймерс, Ф.Р. Штильмарк. - М.: Мыслль, 1978. - 224 с.

24. Реймерс Н. Ф. Природопользование: словарь-справочник [Текст] / Н. Ф. Реймерс. - М.: Мысль, $1990 .-637$ с.

25. Рубель О.Е. Эконология ветландов [Текст] / O.Е. Рубель. - Китинев : Eco-TIRAS. - 2009. - 252 c.

26. Сахаџький O.І., Станкевич С.А. До можливостей оцінювання зволоженості земного покриття за багатоспектральними космічними зображеннями оптичного діапазону на прикладі територї України [Текст] // Доповіді НАН України, 2007. - № 11. - С.122-128.

27. Северо-западная часть Чёрного моря: (биология и экология) [Текст] / [ред. Ю.П. Зайцева, Б.Г. Александрова]. -К.: Наукова Думка, 2006. - С. 351-356.

28. Сербов Н.Г. Оценка экологических рисков загрязнения грунтов (на примере Придунайских районов Одесской области) [Текст] / Н.Г. Сербов, М.Н. Ткачук // Sciences of Europe. - 2019. - T. 3, № 45. - C. 37-45.

29. Свідзінська Д.В. Методи геоекологічних досліджень: геоінформачійний практикум на основі відкритої ГІС SAGA: навчальний посібник [Текст] / Д.В. Свідзінська. - К.: Логос, 2014. - 402 с.

30. Синещеков В.Е. Условия стабильного функиионирования агроландшафтов юга западной Сибири [Текст] / В.Е. Синещеков, А.И. Южаков // География и природные ресурсы, 2005. - № 1. - С. 85-90. 
31. Соколов Е.В. Типизация лиманов северо-западного Причерноморья на основе гидролого-морфометрических характеристик [Текст] / Е.В. Соколов // Наукові записки Тернопільського національного педагогічного університету імені Володимира Гнатюка. Серія: біологія. - 2015. - №1(62). - С. 49-56.

32. Станкевич С.А. Оиінка точності визначення температури штучних та природних земних поверхонь за результатами інфрачервоного космічного знімання [Електронний ресурс] / С.А. Станкевич, В.В. Пилипчук, М.С. Лубський, Г.Б. Крилова // Космічна наука і технологія. - 2016. - Т. 22. - № 4. - С. 19-28. - Режим досmyny: ftp://ftp.mao.kiev.ua/pub/journals/knit/2016-22/knit-2016-22-4-02-Stankevich.pdf

33. Царик Л.П. Геоекологічні підходи до оцінки ступеня збалансованості природокористування [Електронний ресурс] / Л.П. Царик, П.Л. Царик // Вісник Львівського університету. Серія: географія. - 2009. - Вип. 37. C. 43-48. - Режим доступy: http://nbuv.gov.ua/UJRN/VLNU_Geograf_2009_37_7

34. Шищенко П.Г. Прикладная физическая география [Текст] / П.Г. Шищенко. - К.: Вища школа, $1988 .-192$ с.

35. Яиенко В.А. Новый метод дистаниионного оценивания содержания хлорофилла в растительности и его программно-аппаратная реализачия / В.А. Яценко, С.М. Кочубей, П.А. Хандрига, В.В. Донеи // Космічна наука і технологія. - 2007. - T. 13, № 3. - С. 35-44.

36. Dalezios, N.F. (2002). Environmental Remote Sensing, University Teaching, University of Thessaly, Volos. [in Greek].

37. DIRECTIVE 2000/60/EC of the European Parliament and of the Council establishing a framework for the Community action in the field of water policy (2000). http:/leur-lex.europa.eu/legalcontent/EN/TXT/? uri=CELEX:32000L0060

38. Fuller, D.O. (1998). Trends in NDVI time series and their relation to rangeland and crop production in Senegal, 1987-1993. International Journal of Remote Sensing 19(10):2013-2018. https://doi.org/10.1080/014311698215135

39. Izakovičová, Z., Špulerová, J., Petrovič, F. (2018). Integrated approach to sustainable land use management. Environ. Open Access J. Environ. Conserv. Technol., 5, 37. https://doi.org/10.3390/environments5030037

40. Izakovicova, Z., Miklos, L., Miklosova, V. (2018). Integrative Assessment of Land Use Conflicts. Sustainability, 10, 3270. https://doi.org/10.3390/su10093270

41. Marchi, M., Ferrara, C., Biasi, R., Salvia, R., Salvati, L. (2018). Agro-Forest Management and Soil Degradation in Mediterranean Environments: Towards a Strategy for Sustainable Land Use in Vineyard and Olive Cropland. Sustainability, 10, 2565. https://doi.org/10.3390/su10072565

42. Moore, LD., and Burch, G.J. (1985). Physical Basis of the Length-slope Factor in the Universal Soil Loss Equation. Soil Sci. Soc. Am. J. 50: 1294-1298.

43. NASA LP DAAC, 2013. NASA Shuttle Radar Topography Mission (SRTM) Version 3.0 (SRTM Plus) Product Release. Land Process Distributed Active Archive Center, National Aeronautics and Space Adminitration. https://lpdaac.usgs.gov/about/news archive/nasa shuttle radar topography mission srtm version 30 srtm plus product release

44. OpenStreetMap Data Extracts. Geofabrik downloads. URL: http://download.geofabrik.deleurope/ukraine.html

45. Pen, J.; Ma, J.; Du, Y.; Zhang, L.; Hu, X. (2016). Ecological suitability evaluation for mountainous area development based on conceptual model of landscape structure, function, and dynamics. Ecol. Indic., 61, 500-511.

46. Rouse, J.; Haas, R.; Schell, J. Deering, D. (1974). Monitoring vegetation systems in the Great Plains with ERTS. In Proceedings of the Third ERTS-1 Symposium NASA SP-351, Washington, DC, USA, 10-14 December 1973. - Pp. 309-317.

47. Rudenko L., Maruniak E., Lisovskiy S. (2014). Landscape Planning for Ukrainian Rural Communities: Challenges, Outputs, Prospects. Geoadria, 19(2), 191-204.

48. Rudenko L., Maruniak E., Lisovskiy S. (2014). Landscape Planning for Ukrainian Rural Communities: Challenges, Outputs, Prospects. Geoadria, 19(2), 191-204.

49. Sentinel-2B_MSILIC Products. Copernicus Open Access Hub. Available online: https://scihub.copernicus.eu/dhus/\#/home (accessed on 15 September 2019).

50. Stoiko, N., Parsova, V. (2017). Environmental dimensions of rural development in land use planning circumstances in Ukraine. Engineering for rural development, 964-969. https://doi.org/10.22616/erdev2017.16.n197

51. Turner, K.G.; Anderson, S.; Gonzales-Chang, M.; Costanza, R.; Courville, S.; Dalgaard, T.; Dominati, E.; Kubiszewski, I.; Ogilvy, S.; Porfirio, L.; et al. (2016). A review of methods, data, and models to assess changes in the value of ecosystem services from land degradation and restoration. Ecol. Model, 319, $190-207$. https://doi.org/10.1016/j.ecolmodel.2015.07.017

52. USGS GlobalVisualizationViewer. URL: http://glovis.usgs.gov/

53. Using the USGS Landsat 8 Product. URL: http://landsat.usgs.gov/Landsat8_Using_Product.php.

54. Wilson, E. H. \& Sader, S. A. (2002). Detection of forest harvest type using multiple dates of Landsat TM imagery. Remote Sensing of Environment, 80 (3), 385-396. DOI: https://doi.org/10.1016/S0034-4257(01)00318-2

55. Yang, J.; Li, S.; Lu, H. (2019). Quantitative influence of land-use changes and urban expansion intensity on landscape pattern in Qingdao, China: Implications for urban sustainability. Sustainability, 11, 61-74 https://doi.org/10.3390/su11216174

Authors Contribution: All authors have contributed equally to this work. 
UDC: 504.064 (262.5) (477.74)

\section{Yevhen Sokolov,}

$\mathrm{PhD}$ (Biology), Senior Researcher,

State Institution «Institute of Marine Biology of the NAS of Ukraine»,

37 Pushkinska St., Odessa, 65011, Ukraine, e-mail: sokolovev87@gmail.com, https://orcid.org/0000-0002-0587-2719;

Roman Shevchenko,

$\mathrm{PhD}$ (Engineering Sciences), Associate Professor of the Department of Ecology and

Environmental Technologies, «Odesa National Academy of Food Technologies»,

112 Kanatna St., Odessa, 65039, Ukraine,

e-mail: onaft.eko@gmail.com, https://orcid.org/0000-0002-7924-1987;

\section{Mariia Madani,}

$\mathrm{PhD}$ (Engineering Sciences), Associate Professor of the Department of Ecology and

Environmental Technologies, «Odesa National Academy of Food Technologies», e-mail: madanikader50@ gmail.com, http://orcid.org/0000-0001-9386-7364

\section{ECOLOGICAL ASSESSMENT OF THE TERRITORIAL COMPLEXES OF TATARBUNARS'KYI DISTRICT OF ODESSA REGION}

Formulation of the problem. The Tatarbunars'kyi District is located in the southwestern part of Odessa region and reflects the main features of the landscape-economic structure of the region: water, agricultural, resort and environmental areas. On the other hand, the form of land use is characterized by widespread plowing of land with degradation and erosion of soil cover.

Land structure and use patterns have a complex negative impact on ecological and economic processes and cannot ensure the sustainable development of the region, in particular it is antagonistic to the unique transitional wetland ecosystems of international importance located within the area.

To solve the issues of balanced environmental management and zoning of the landscape and economic structure of the region, Earth remote sensing (ERS) data can be used - spectrozonal satellite imagery and geographic information systems (GIS), which can simultaneously cover the research area as a whole, carry out regular monitoring and significantly reduce costs by expensive expeditionary work. Using space monitoring data allows you to get a large array of characteristics of the state of the territorial complexes of the region.

Purpose of the work is: assessment of the ecological state of the landscape economic structure and development of recommendations for the protection of natural and territorial complexes of the Tatarbunar'skyi District of Odessa region based on the use of GIS and remote sensing data.

Methods. Landsat8 satellite images with OLI and TIRS sensors, digital terrain models (SRTM) with a spatial resolution of $30 \mathrm{~m}$ were used as initial data. The spatial distribution of the population was carried out on the basis of OpenStreetMap data using automatic interpolation using the IDW method. Spatial analysis and data processing were carried out in the QGIS v3.4.6 software package. To quantify the vegetation cover, the Normalized Difference Vegetation Index - NDVI was calculated. Waterlog distribution was estimated using a modified normalized differential moisture index (NDMI). The analysis of the structure of land use and anthropogenic load was carried out on the basis of ranking of territorial objects into homogeneous groups to calculate geoecological coefficients.

Results. The article discusses the possibilities of using Earth remote sensing data for a functional assessment of land changes as a result of anthropogenic activities, primarily arable land, analyzes the ecological and economic equilibrium of the region based on geoecological coefficients, identifies areas that are primarily exposed to environmental risks, exogenous processes and the impact anthropogenic factors. Measures are proposed to increase the environmental sustainability of agrolandscapes and the landscape-anthropogenic structure of the region's lands. A detailed hydrological and morphometric analysis of the catchment basin was carried out. Karachaus within the boundaries of the District. For the catchment estuary, remediation and nature conservation measures based on GIS are proposed and designed

Keywords: Tatarbunars'kyi District, northwestern Black Sea region, GIS analysis, remote sensing, anthropogenic load, ecological and economic balance.

\section{References}

1. Tuchkovenko Yu.S., Gopchenko E. D. (Ed). (2011). Actual problems of estuaries of the northwestern Black Sea region: Collective monograph. Odessa: TPP, 224. 
2. Andreev S.M. Krasovskiy G.Ya., Solovei V.V. (2011). Method for soil fertility estimation with the use of space surveys (on the base of Tatarbunary district in Odessa region). Scientific Notes of Taurida National V. I. Vernadsky University. Series: Geography. 24 (63), 3, 16-23.

3. Balakay G.T., Balakai N.I., Poluektov E.V., Babichev A.N., Voevodina L.A., Yurina L.I. Techniques for increasing land bio-productivity, preserving soil fertility and ecological sustainability of agrolandscapes. Novocherkassk, 71.

4. Water Code of Ukraine as amended by the Verkhovna Rada of Ukraine dated 09.04.2014 for 1193-VII (1193-18). K., 38.

5. Gladun G.B., Gladun Yu.G., Yerevskaya L.V. (2014). Adaptive-landscape principles of application of fieldprotective forest cultivation in the Odessa region. Agrochemistry and Soil Science, 81, 59-65.

6. Gorun V.V., Pilipenko G.P., Turcan O.I. (2012). A comprehensive assessment of the recreational potential of administrative districts of Odessa region. Krajobraz i turystyka $w$ warunkach zrownowazonego rozwoju. Landscape and tourism in a sustainable develophent. Kielce-Sobkow, 43 (1), 55-57.

7. Donets V.V., Kochubey S.M., Yatsenko V.A., Kazantsev T.A., Brovchenko V.V. (2013). Creation of the field spectral hardware-software complex for subsatellite validation of the controlled from distance research of vegetation. Systems for processing information, 8 (115), 36-42.

8. The region's environmental passport for 2018. [Electronic resource]. Available at: http://ecology.odessa.gov.ualekologchnij-pasport-regonu/

9. Filippovich V.E., Lyalko V.I., Stankevich S.A., Krilova G.B., Michak A.G. (2013). Use of satellite imagery in the analysis of the thermal field of the historical part of Kiev. Problems and experience of engineering protection of urban areas and preservation of heritage under conditions of geo-ecological risk. Kyiv: Phoenix, 6, 64-69.

10. Kochubey S.M. Equipment and methods for remote sensing of vegetation in the optical range (2002). Space science and technology, 8(2/3), 271-275.

11. Kochurov B.I. (1999). Geoecology: ecological diagnostics and ecological and economic balance of the territory. Smolensk: SSU, 154.

12. Lyalko V.I., Popov M.A. (Ed.). (2006). Multispectral methods for remote sensing of the Earth in the problems of nature management. Kiev, Naukova Dumka, 358.

13. Makevnin S.G. (1991). Nature Protection. Moscow, 127.

14. Minicheva G.G., Sokolov E.V. (2014). Assessment of natural resistance of estuaries in the Northwest Black Sea region in accordance with the EU WFD principles. Scientific reports of the National University of Life and Environmental Sciences of Ukraine, (5). Available at: http://nbuv.gov.ua/j-pdf/Nd2014_5_7.pdf

15. Mukhin Yu.P., Kuzmina T.S., Baranov V.A. (2002). Sustainable development: environmental optimization of agroand urban landscapes: Textbook. Allowance. Volgograd, 127.

16. Odum Yu. (1975). Fundamentals of Ecology. Moscow: Mir, 740.

17. Popova O.L. (2012). Ecodiagnostics of the natural-economic organization of the territory of Ukraine: agrolandscape aspect. Economics and forecasting, (3), 92-101. Available at: http://nbuv.gov.ua/UJRN/econprog 2012_3_9

18. Popov M.O., Semko I.D. (2013). Assessment of green planting characteristics by using methods of remote sensing of Earth. Fundamentals of environmental management and life safety. 2013, 12, 51-62.

19. Popova O.M. (2016). Morphometry and toponymy of the hydrological objects of the Tuzlovsky estuaries, national park. Bulletin of ONU. Series of geogr. and geol. science. 21, 2 (29), 64-84.

20. Popova O. M. (2017). Natural-reserve fund of Odessa region in the system of physical and geographical zoning of Ukraine and ways of its optimization. Bulletin of the Odessa National University. Series: Geographical and Geological Sciences. 22 (2), 29-47. Available at: http://nbuv.gov.ua/UJRN/Vonu_geo_2017_22_2_4

21. Paramonov E.G. Paramonov E.G., Ishutin Y. N., Simonenko A. P. (2003). Kulundinskaya steppe: desertification problems. Barnaul: Alt. Univ., 138.

22. Parfenova N. I., Parfenova N. I., Reshetkina N. M. (1993). Energy natural-zonal indicators and the prospect of their application in land reclamation. Land reclamation and water management. 1, 3-5.

23. Reimers N.F., Shtilmark F.R. (1978). Protected areas. Moscow, Mysl, 224.

24. Reimers N. F. (1990). Nature management: dictionary-reference book. Moscow: Mysl, 637.

25. Rubel O.E. (2009). Econology of the Wetlands. Kishinev, Eco-TIRAS, 252.

26. Sahatsky O.I., Stankevich S.A. (2007). To the possibility of assessing the humidity of the earth multispectral space coatings optical range images by example the territory of Ukraine. Reports of the NAS of Ukraine, 11, 122-128.

27. Zaitsev Yu. P., Alexandrova B. G. (Ed). (2006). North-Western part of the Black Sea: (biology and ecology) . Kiev, Naukova Dumka, 351-356.

28. Serbov N.G., Tkachuk M.N. (2019). Methodological approches to the determination of enviromental risks of soil pollution (on the example of the Danube districts of Odessa region). Sciences of Europe, 3, (45), 37-45.

29. Svidzinska D.V. (2014). Methods of geoecological research: geoinformation workshop on the basis of open GIS SAGA: textbook. Kiev, Logos, 402.

30. Sineshchekov V.E., Yuzhakov A.I. (2005). Conditions for the stable functioning of agrolandscapes in the south of western Siberia. Geography and Natural Resources, 1, 85-90.

31. Sokolov E.V. (2015). Typization of estuaries of the northwestern Black Sea on the basis of hydrologicmorphometric characteristics. Scientific Notes of the Ternopil National Pedagogical University named after Vladimir Gnatyuk. Series: Biology, 1 (62), 49-56. 
32. Stankevich S.A. (2016). Accuracy estimation of the temperature of artificial and natural Earth's surfaces determining by infrared satellite imagery. Space science and technology, 22(4), 19-28. Available at: ftp://ftp.mao.kiev.ua/pub/journals/knit/2016-22/knit-2016-22-22-4-02-Stankevich.pdf

33. Tsarik, L.P., Tsarik P.L. (2009). Geoecological Approaches to Assessing the Balance of Environmental Management. Series: Geography. 37, 43-48. Available at: http://nbuv.gov.ua/UJRN/VLNU_Geograf 2009377

34. Shishchenko P.G. (1988). Applied physical geography. Kiev, High School, 192.

35. Yatsenko V.A. (2007). New method for remote estimation of chlorophyll content in vegetation and its software realization. Space science and technology, 13 (3), 35-44.

36. Dalezios, N.F. (2002). Environmental Remote Sensing, University Teaching, University of Thessaly, Volos. [in Greek].

37. DIRECTIVE 2000/60/EC of the European Parliament and of the Council establishing a framework for the Community action in the field of water policy (2000). Available at: http:/leur-lex.europa.eu/legalcontent/EN/TXT/? uri=CELEX:32000L0060

38. Fuller, D.O. (1998). Trends in NDVI time series and their relation to rangeland and crop production in Senegal, 1987-1993. International Journal of Remote Sensing 19(10):2013-2018. https://doi.org/10.1080/014311698215135

39. Izakovičová, Z., Špulerová, J., Petrovič, F. (2018). Integrated approach to sustainable land use management. Environ. Open Access J. Environ. Conserv. Technol., 5, 37. https://doi.org/10.3390/environments5030037

40. Izakovicova, Z., Miklos, L., Miklosova, V. (2018). Integrative Assessment of Land Use Conflicts. Sustainability, 10, 3270. https://doi.org/10.3390/su10093270

41. Marchi, M., Ferrara, C., Biasi, R., Salvia, R., Salvati, L. (2018). Agro-Forest Management and Soil Degradation in Mediterranean Environments: Towards a Strategy for Sustainable Land Use in Vineyard and Olive Cropland. Sustainability, 10, 2565. https://doi.org/10.3390/su10072565

42. Moore, LD., and Burch, G.J. (1985). Physical Basis of the Length-slope Factor in the Universal Soil Loss Equation. Soil Sci. Soc. Am. J. 50: 1294-1298.

43. NASA LP DAAC, 2013. NASA Shuttle Radar Topography Mission (SRTM) Version 3.0 (SRTM Plus) Product Release. Land Process Distributed Active Archive Center, National Aeronautics and Space Adminitration. https://lpdaac.usgs.gov/about/news archive/nasa shuttle radar topography mission srtm version 30 srtm plus product release.

44. OpenStreetMap Data Extracts. Geofabrik downloads. Available at: http://download.geofabrik.deleuropelukraine.html

45. Pen, J.; Ma, J.; Du, Y.; Zhang, L.; Hu, X. (2016). Ecological suitability evaluation for mountainous area development based on conceptual model of landscape structure, function, and dynamics. Ecol. Indic., 61, 500-511.

46. Rouse, J.; Haas, R.; Schell, J.; Deering, D (1974). Monitoring vegetation systems in the Great Plains with ERTS. In Proceedings of the Third ERTS-1 Symposium NASA SP-351, Washington, DC, USA, 10-14 December 1973, $309-317$.

47. Rudenko L., Maruniak E., Lisovskiy S. (2014). Landscape Planning for Ukrainian Rural Communities: Challenges, Outputs, Prospects. Geoadria, 19(2), 191-204.

48. Rudenko L., Maruniak E., Lisovskiy S. (2014). Landscape Planning for Ukrainian Rural Communities: Challenges, Outputs, Prospects. Geoadria, 19(2), 191-204.

49. Sentinel-2B_MSILIC Products. Copernicus Open Access Hub. Available at: https://scihub.copernicus.eu/ dhus/\#/home (accessed on 15 September 2019).

50. Stoiko, N., Parsova, V. (2017). Environmental dimensions of rural development in land use planning circumstances in Ukraine. Engineering for rural development, 964-969. https://doi.org/10.22616/erdev2017.16.n197

51. Turner, K.G.; Anderson, S.; Gonzales-Chang, M.; Costanza, R.; Courville, S.; Dalgaard, T.; Dominati, E.; Kubiszewski, I.; Ogilvy, S.; Porfirio, L.; et al. (2016). A review of methods, data, and models to assess changes in the value of ecosystem services from land degradation and restoration. Ecol. Model, 319, $190-207$. https://doi.org/10.1016/j.ecolmodel.2015.07.017

52. USGS GlobalVisualizationViewer. Available at: http://glovis.usgs.gov/

53. Using the USGS Landsat 8 Product. Available at: http://landsat.usgs.gov/Landsat8_Using_Product.php.

54. Wilson, E. H. \& Sader, S. A. (2002). Detection of forest harvest type using multiple dates of Landsat TM imagery. Remote Sensing of Environment, 80 (3), 385-396. https://doi.org/10.1016/S0034-4257(01)00318-2

55. Yang, J.; Li, S.; Lu, H. (2019). Quantitative influence of land-use changes and urban expansion intensity on landscape pattern in Qingdao, China: Implications for urban sustainability. Sustainability, 11, 61-74 https://doi.org/10.3390/su11216174 